\title{
Restoration of the external Scandinavian Caledonides
}

\author{
A. HUGH N. RICE* $\dagger \&$ MARK W. ANDERSON $\ddagger$ \\ * Department of Geodynamics \& Sedimentology, University of Vienna, Geozentrum, Althanstrasse 14, 1090 Vienna, \\ Austria \\ $\ddagger$ School of Geography, Earth \& Environmental Sciences, Plymouth University, Portland Square, Drake Circus, \\ Plymouth, Devon, PL48AA, England
}

(Received 19 November 2015; accepted 30 March 2016; first published online 13 July 2016)

\begin{abstract}
Three models are evaluated for restoring basement rocks coring tectonic windows (WindowBasement) in the Scandinavian Caledonides; parautochthonous (Model I) and allochthonous (models II/III), with initial imbrication of the Window-Basement post-dating or pre-dating, respectively, that in the external imbricate zone (Lower Allochthon). In Model I, the Window-Basement comes from the eastern margin of the basin now imbricated into the Lower Allochthon, while in models II/III it comes from the western margin. In Model II, the Window-Basement formed a basement-high between Tonian and Cryogenian sediments imbricated into the Middle and Lower allochthons; in Model III deposition of the Lower Allochthon sediments commenced in Ediacaran times. Balanced cross-sections and branch-line restorations of four transects (Finnmark-Troms, Västerbotten-Nordland, JämtlandTrøndelag, Telemark-Møre og Romsdal) show similar restored lengths for the models in two transects and longer restorations for models II/III in the other transects. Model I can result in c. $280 \mathrm{~km}$ wide gaps in the restored Lower Allochthon, evidence for which is not seen in the sedimentology. The presence of $<3 \mathrm{~km}$ thick alluvial-fan deposits at the base of the Middle Allochthon indicates proximal, rapidly uplifting basement during Tonian-Cryogenian periods, taken as the origin of the Window-Basement during thrusting in models II/III. Model I requires multiple changes in thrusting-direction and predicts major thrusts or back-thrusts, currently unrecognized, separating parts of the Lower Allochthon; neither are required in models II/III. Metamorphic data are consistent with models II/III. Despite considerable along-strike structural variability in the external Scandinavian Caledonides, models II/III are preferred for the restoration of the Window-Basement.
\end{abstract}

Keywords: Lower Allochthon, basement massif, tectonic window, structure, balanced cross-section, branch-line.

\section{Introduction}

Basement rocks crop out in tectonic windows in many orogens, doming the structurally overlying units (Rodgers, 1995). Although such rocks (here neutrally called Window-Basement) occur throughout the Scandinavian Caledonides (Fig. 1; Gee et al. 1985b, 2008), their structural status remains uncertain, causing problems in palaeogeographic reconstructions and interpretations of the late- to post-Caledonian structural evolution (extension) of Baltica.

Here, two previously proposed structural and palaeogeographic models for the restoration of the external parts of the Scandinavian Caledonides (i.e. the structurally lower and predominantly brittle deformed parts) are compared from four areas. Model I presumes that the Window-Basement is parautochthonous and Model II assumes that it is allochthonous. A third model (Model III), combining aspects of the other models, is proposed for some parts of the orogen.

Restorations of the areas selected (east Finnmark to east Troms; Västerbotten to Nordland; Jämtland to north Trøndelag; and Telemark to Møre og Romsdal) have been published previously (Fig. 1; Gayer \&

$\nmid$ Author for correspondence: alexander.hugh.rice@univie.ac.at
Roberts, 1973; Gee, 1975, 1978; Gayer et al. 1987; Gayer \& Greiling, 1989; Rice, 2005, 2014; Andersen et al. 2012). Definitive new restorations are not necessarily given here, due to some uncertainties in the input data. Rather, a range of alternatives are critically evaluated; at issue is whether the models are equally valid and if the same model must be applied throughout the orogen.

All deformation and metamorphic grades referred to here are of Caledonian age. In this text, basement refers to rocks formed (deposited/intruded) prior to the Caledonian Wilson Cycle, while cover refers to rocks formed during the Caledonian Wilson Cycle. $\mathrm{Al}$ lochthonous and autochthonous refer, respectively, to whether rocks were, or were not, deformed (thrusttransported, extended) during the Caledonian Orogeny. These give four possibilities - autochthonous basement, autochthonous cover, allochthonous basement and allochthonous cover - all of which are relevant here. This paper is not concerned with basement-cover (unconformity) relationships.

\section{Scandinavian Caledonides overview}

The Scandinavian Caledonides have been divided into the Uppermost, Upper, Middle and Lower allochthons 


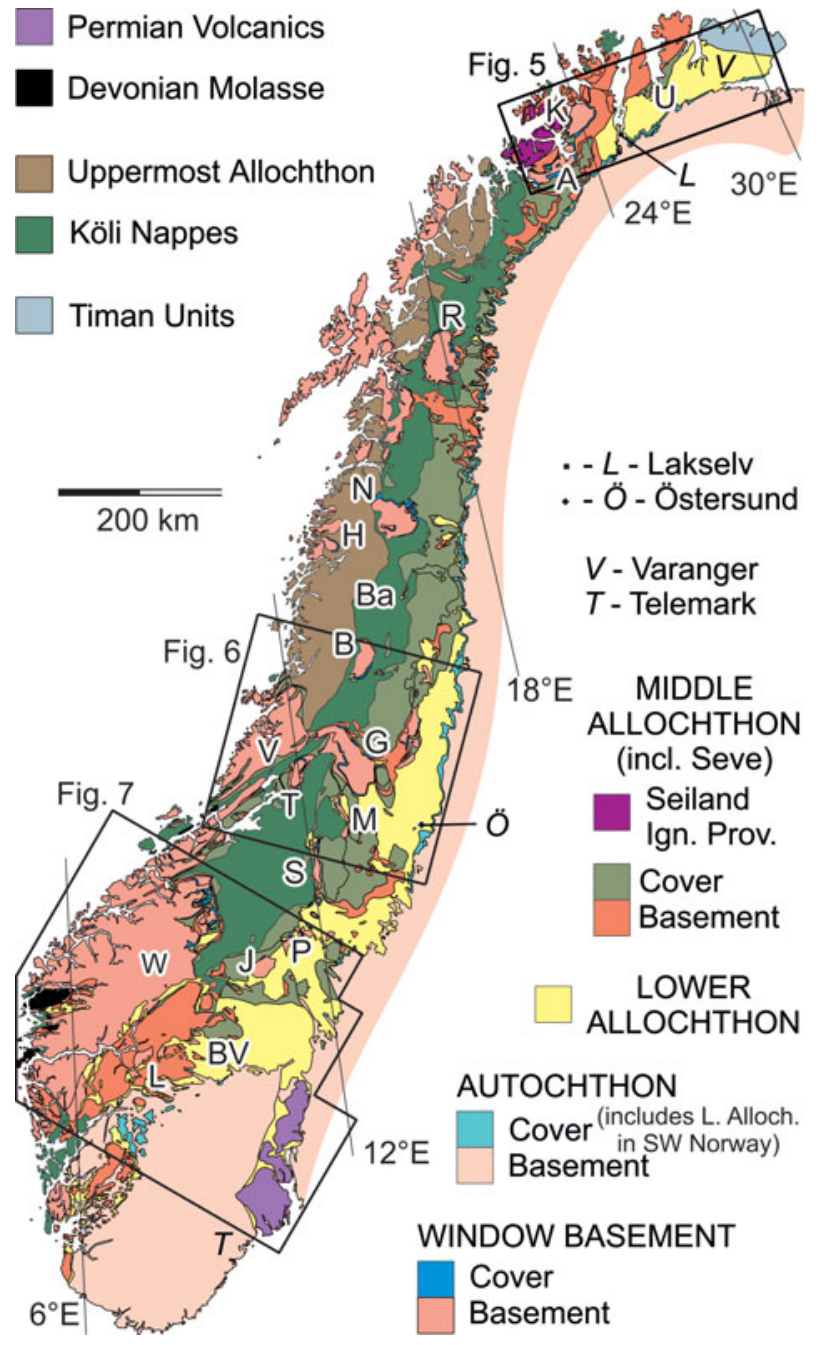

Figure 1. Distribution of the main tectonic units within the Scandinavian Caledonides (modified from Gee et al. 1985b). Areas covered by Figures 5-7 are shown. Window-Basement (from north to south): U - Kunes; $\mathrm{K}$ - Komagfjord; AK - AltaKvænangen; R-Rombak; N-Nasafjäll; H-Høgtuva; Ba-Bångonåive; B - Børgefjell; V - Vestranden; GO - Grong-Olden; T - Tømmerås; M - Mullfjället; S - Sylarna; P - Spekedalen; J - Atnsjøen; BV- Beito-Vang; L - Aurdal-Lærdal; W - Western Gneiss Region.

overlying an Autochthon (Gee et al. 1985b, 2008; Fig. 1), although the value of these terms has been criticised recently (Corfu, Andersen \& Gasser, 2014). To simplify regional correlations between the cover sediments in the Autochthon, the Lower and Middle allochthons and the Window-Basement, which were all derived from the Iapetus Baltoscandian continental margin and are lithologically comparable (e.g. Nystuen \& Siedlecka, 1988; Nystuen et al. 2008), the stratigraphy has been divided here into nine informal successions (S1a-S8; Table 1). In the following text, the succession number is given without further reference to Table 1 . Except for the basal thrust sheets, the Middle Allochthon is generally not discussed here.

The Autochthon comprises dominantly clastic rocks overlying the crystalline Baltic Shield. Except in NE Norway, the sediments are of syn- to post-Gaskiers gla-
Table 1. Simplified lithostratigraphy of the Iapteus Baltoscandian continental margin

\begin{tabular}{|c|c|c|}
\hline Succession & Age & Lithologies \\
\hline S8 & $\begin{array}{l}\text { Post-early Ordovician- } \\
\text { Devonian }\end{array}$ & Carbonate and clastic \\
\hline S7 & $\begin{array}{l}\text { middle Cambrian - } \\
\text { early Ordovician }\end{array}$ & $\begin{array}{l}\text { (Anoxic) black } \\
\text { shale + carbonates }\end{array}$ \\
\hline S6 & $\begin{array}{l}\text { Ediacaran - early } \\
\text { Cambrian }\end{array}$ & $\begin{array}{l}\text { Fluvial to marine } \\
\text { clastics and } \\
\text { carbonates }\end{array}$ \\
\hline S5 & Ediacaran (c. $580 \mathrm{Ma})$ & $\begin{array}{l}\text { Gaskiers glacial } \\
\text { deposits }\end{array}$ \\
\hline S4 & Ediacaran & $\begin{array}{l}\text { Fluvial to marine } \\
\text { clastics }\end{array}$ \\
\hline S3 & $\begin{array}{l}\text { late Cryogenian } \\
\text { (c. } 640 \mathrm{Ma})\end{array}$ & $\begin{array}{l}\text { Marinoan glacial } \\
\text { deposits }\end{array}$ \\
\hline S2 & Cryogenian & $\begin{array}{l}\text { Marine dolomites and } \\
\text { fine clastics }\end{array}$ \\
\hline $\mathrm{S} 1 \mathrm{~b}$ & Tonian-Cryogenian & $\begin{array}{l}\text { Fluvial to marine } \\
\text { clastics }\end{array}$ \\
\hline S1a & Tonian-Cryogenian & Coarse conglomerates \\
\hline
\end{tabular}

ciation (S5, late Ediacaran, c. $580 \mathrm{Ma}$; Bowring et al. 2003) or younger age, and typically have a condensed thickness $(<300 \mathrm{~m})$ compared to equivalent units in the Lower Allochthon (Føyn, 1967, 1985; Gee et al. 1974; Andresen, 1978; Rickard et al. 1979; Thelander, 1982; Bockelie \& Nystuen, 1985; Gayer \& Greiling, 1989; Bierlein \& Greiling, 1993; Page, 1993; Nielsen \& Schovsbo, 2006). The upper part frequently comprises mechanically weak graphitic shales (S7; Gee et al. 1974; Thelander, 1978; Morley, 1986; Gayer \& Greiling, 1989; Bierlein \& Greiling, 1993). Metamorphic studies (mostly illite crystallinity) indicate a diagenetic - lower anchizone alteration (Bergström, 1980; Kisch, 1980; Snäll, 1988; Anderson, 1989; Rice et al. 1989a; Warr, Greiling \& Zachrisson, 1996).

The Lower Allochthon (external imbricate zone) overlies the Autochthon along the Caledonian basal décollement, except in Telemark and Varanger (south and NE Norway, respectively; Fig. 1), where deformation dies out gradually without a major thrust (Morley, 1986; Townsend, 1987). Hossack \& Cooper (1986) suggested that the pre-erosional Caledonian thrust-front in the central Scandinavian Caledonides lay c. 90-120 km east of the present-day front. Anderson (1989) used metamorphic criteria to constrain the pre-erosion front in the Rombak area (Fig. 1) to c. $120 \mathrm{~km}$ east of the present-day eroded thrust front; this is very similar to the $110 \mathrm{~km}$ proposed by Hossack \& Cooper (1986). In contrast, Garfunkel \& Greiling (1998) estimated that the pre-erosional thrust-front lay c. $80 \mathrm{~m}$ east of the eroded thrust front in the Västerbotten area, considerably less than the $120 \mathrm{~km}$ inferred by Hossack \& Cooper (1986).

Brittle imbrication in the Lower Allochthon, mostly with thrust shortening of $<60 \%$ (Chapman, Gayer \& Williams, 1985; Hossack, Garton \& Nickelsen, 1985; Morley, 1986, 1987a , 1987b; Townsend et al. 1986; Gayer \& Greiling, 1989; Townsend, Rice \& Mackay, 1989; Bierlein \& Greiling, 1993; Greiling, Gayer \& Stephens, 1993) occurred during diagenetic zone to anchizone metamorphism (Kisch, 1980; Anderson, 
Table 2. Succession 1a conglomerates in the base of the Middle Allochthon

\begin{tabular}{lllcl}
\hline Transect & \multicolumn{1}{c}{ Structural unit } & \multicolumn{1}{c}{ Stratgraphic unit } & Thickness $(\mathrm{km})$ & \multicolumn{1}{c}{ Reference } \\
\hline 1 & Laksefjord Nappe Complex & Ifjord Formation & 3.0 & Føyn, Chapman \& Roberts (1983) \\
2 & Stalon Nappe Complex & Risbäck Group equivalent* & 0.25 & Greiling (1989) \\
3 & Offerdal Nappe & Offerdal Conglomerate & $>0.3$ & Plink-Björklund, Björklund \& Loorents (2005) \\
4 & Valdres Nappe & Ormtjernskampen Conglomerate & 0.8 & Nickelsen (1974) \\
4 & Valdres Nappe & Bygdin Conglomerate & 2.4 & Hossack (1978) \\
\hline
\end{tabular}

*These may partly be younger than S1a (Greiling, pers. comm. 2016).

1989; Rice et al. 1989a; Warr, Greiling \& Zachrisson, 1996; Angerer \& Greiling, 2012).

The Lower Allochthon preserves a fluvial to shallowmarine, predominantly clastic, sedimentary succession of Tonian-Devonian age (S1-S8; Gee et al. 1974; Bjørlykke, Elvsborg \& Høy, 1976; Johnson, Levell \& Siedlecki, 1978; Nystuen, 1982, 1987; Basset, Cherns \& Karis, 1982; Kumpulainen \& Nystuen, 1985; Nystuen \& Siedlecka, 1988; Roberts \& Stephens, 2000; Nystuen et al. 2008).

The Middle Allochthon comprises ductilely deformed nappes of both cover and basement lithologies (Fig. 1). The cover includes predominantly clastic, fluvial to shallow-marine sediments of Tonian and younger ages (S1b-S7; Kumpulainen, 1980; Føyn, Chapman \& Roberts, 1983; Bockelie \& Nystuen, 1985; Kumpulainen \& Nystuen, 1985; Nickelsen, Hossack \& Garton, 1985; Greiling, 1989), sometimes with very thick, proximally derived alluvial-fan basal conglomerates (S1a; Nickelsen, 1974; Hossack, 1978; Føyn, Chapman \& Roberts, 1983; Gayer \& Greiling, 1989; Plink-Björklund, Björklund \& Loorents, 2005; Nystuen et al. 2008; Table 2).

The Window-Basement crops out throughout the length of the orogen (Fig. 1), with different tectonic windows showing slightly different features. For example, the Western Gneiss Region is extremely large and underwent ultra-high-pressure metamorphism in its internal parts (Hacker et al. 2003) while the Kunes Nappe (Rice, 2001) is very small and underwent low- to middle-greenschist facies alteration (Føyn, Chapman \& Roberts, 1983). The Nasafjäll Window-Basement comprises two exposed, relatively large, basementcover slices (Thelander, Bakker \& Nicholson, 1980), as do several other areas of Window-Basement in Central Scandinavia (Tømmerås, Grong-Olden, Mullfjället, Western Gneiss Region; Fig. 1), while the Bångonåive Window-Basement comprises a large number of small and thin basement-cover imbricates (Greiling, Gayer \& Stephens, 1993). Other Window-Basement units comprise a single exposed slice of basement (AurdalLærdal, Vang, Beito, Atnsjøen, Spekedalen, Børgefjell, Rombak, Alta-Kvænangen, Altenes, Komagfjord, Kunes), although these may have minor amounts of internal shortening (e.g. Fareth, 1979; Greiling, 1988).

Despite this variability, the Window-Basement can be summarized as consisting of a central tectonic unit (Parautochthon of Gee et al. 1985b), often with a lithologically comparable upper unit (Gee, 1980; Krill, 1980, 1985; Thelander, Bakker \& Nicholson, 1980; Roberts, 1989, 1997; Fig. 1). Both units may locally have an unconformable cover succession, usually of Ediacaran (S5) or younger age and condensed compared to the Lower and Middle Allochthon successions, but similar to those forming the Autochthon (Brown \& Wells, 1966; Gee, 1980; Krill, 1980; Thelander, Bakker \& Nicholson, 1980; Nystuen \& Ilebekk, 1981; Siedlecka \& Ilebekk, 1982; Lindqvist, 1984, 1988; Føyn, 1985; Pharaoh, 1985; Björklund, 1987; Bax, 1989; Gayer \& Greiling, 1989; Schouenborg, 1989; Greiling, Gayer \& Stephens, 1993).

The metamorphic grade of the Window-Basement cover sediments is higher or equivalent to that in the adjacent Lower Allochthon and generally, but not always, lower or equivalent to that in the overlying Middle Allochthon (e.g. Andréasson \& Gorbatschev, 1980; Lindqvist \& Johansson, 1987; Anderson, 1989; Rice et al. 1989a; Lindqvist, 1990; Table 3).

Construction of a 'generalized' cross-section through the orogen is not possible, not only because of the uncertainty in the restoration of the WindowBasement, which has an important effect on the geometry of the basal décollement towards the hinterland, but also because significant along-strike changes in the development of the orogen, including the variable development of the Uppermost and Lower allochthons

Table 3. Variation in peak metamorphic grade across the transects. NA - data not available; NP - unit not preserved (eroded away) or not developed; L, M, U - lower, middle, upper; Ec, Am, G, Ep, An, D - eclogite, amphibolite, greenschist, epizone, anchizone, diagenetic zone facies alteration.

\begin{tabular}{|c|c|c|c|c|c|c|c|}
\hline \multirow[b]{3}{*}{ Transect } & \multicolumn{7}{|c|}{ Tectonic units } \\
\hline & \multicolumn{2}{|c|}{ MA } & \multicolumn{2}{|c|}{ WB } & \multicolumn{2}{|c|}{ LA } & \multirow[t]{2}{*}{$\mathrm{PA} / \mathrm{A}$} \\
\hline & Upper & Lower & Upper/internal & Lower/external & Internal & External & \\
\hline 1 & NA & Ep & NP & $\mathrm{Ep}$ & Ep-D & LAn-D & $\mathrm{D}$ \\
\hline 2 & LAm-UG & LAm-UG & NA & MG-Ep & Ep-An & NP & LAn-D \\
\hline 3 & LAm-UG & LAm-UG & UAm-MAm & MG & Ep-D & NP & D \\
\hline 4 & NA & MG & $\mathrm{Ec}$ & (M-L?)G & MG-LG/Ep & $\mathrm{D}$ & $\mathrm{D}$ \\
\hline
\end{tabular}




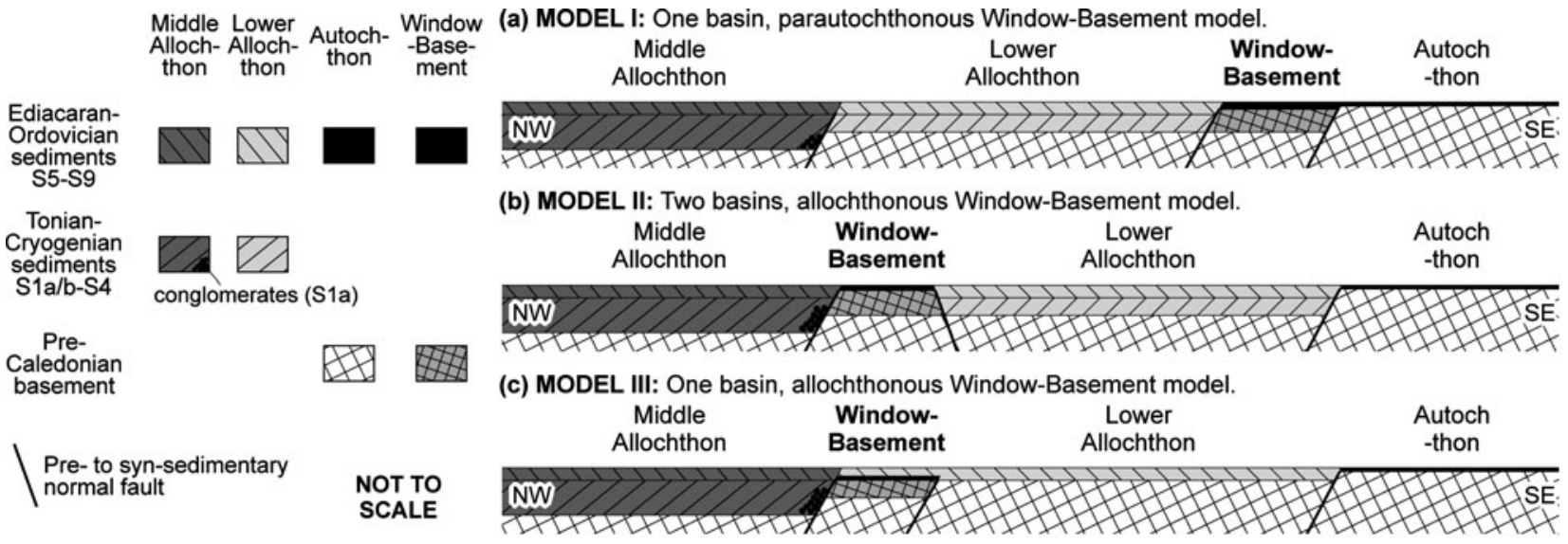

Figure 2. Schematic representation of the models used to restore the Window-Basement and external part of the Scandinavian Caledonides: (a) paratochthonous, one-basin model (Gee, 1975); (b) allochthonous two-basin model (Gayer \& Roberts, 1973); and (c) combined model with allochthonous Window-Basement and one basin. See Discussion (Section 6.c.4) for details.

and also the amount of basement in the Lower and Middle allochthons (e.g. Björklund, 1985, unpub. PhD thesis, Chalmers Tekniska Högskola, Göteborgs University, Sweden, 1989; Fig. 1), preclude any such crosssection at a meaningful level.

\section{Published restorations of the Window-Basement}

Only thrusting-related models for the restoration of the Window-Basement are reviewed here. Models in which exposure of the Window-Basement is linked to postCaledonian normal faulting (Osmundsen et al. 2005) are evaluated in the Discussion (Section 6.f).

\section{3.a. One-basin model: parautochthonous Window-Basement (Model I)}

In central Jämtland, Gee (1975) and Dyrelius et al. (1980) proposed that the Müllfjället and Tømmerås Window-Basement (Fig. 1) were parautochthonous (or allochthonous, but not far-travelled, if an upper imbricate of the Window-Basement). They were derived from a step in the basement topography at the eastern margin of the Tonian-Cryogenian basin (S1b, S2) that formed on the Baltoscandian continental margin (Fig. 2a). The Window-Basement was, therefore, imbricated during late shortening in the Lower Allochthon. The thin, upper Ediacaran - lower Palaeozoic autochthonous sedimentary cover succession (S6, S7) was inferred to continue unbroken from the Caledonian front to the Window-Basement, everywhere resting directly on the basement, giving an autochthonous cover of at least $c$. $200 \mathrm{~km}$ width. This inference was supported by borehole data in the Tåsjön area that traced autochthonous sediments (S7) for $30 \mathrm{~km}$ west of the Caledonian front (Gee, Kumpulianen \& Thelander, 1978) and by seismic data (Palm et al. 1991;Fig. 3). Gee et al. (1985a) presented a similar model in which the shelf deepened stepwise to the west, reflecting the eastwards onlap of the cover onto the Window-Basement (Fig. 4). Although the scales are approximate in Figure 4, the distances from Östersund to Müllfjället and Tømmerås are essentially the present-day distances (Fig. 1). Further, the youngest sediments in the basin (S8) have been restored to above or west of the Tømmerås WindowBasement, whereas currently they lie east of Tømmerås. The Middle Allochthon sediments represent a continuation of the Lower Allochthon basin in Model I, reflecting a westwards deepening of the continental

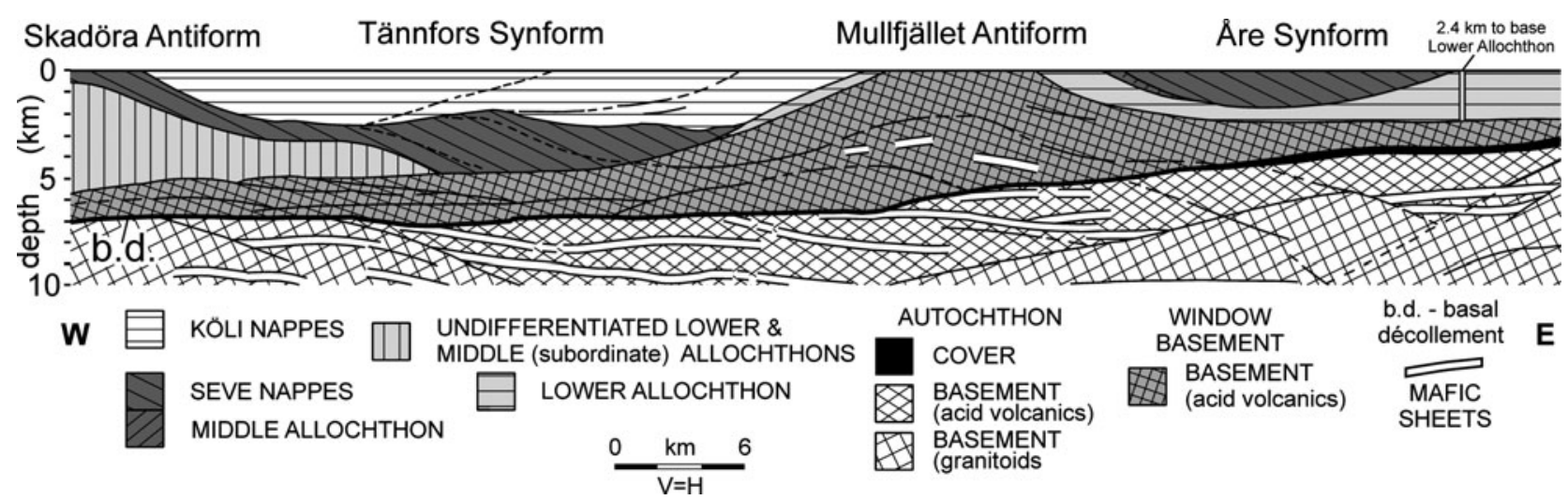

Figure 3. Upper $10 \mathrm{~km}$ of the seismic interpretation of the structure of the central part of the Scandinavian Caledonides (from Palm et al. 1991). Note the smoothed ramp-flat appearance of the basal décollement. See Figure 6 for the profile line. 


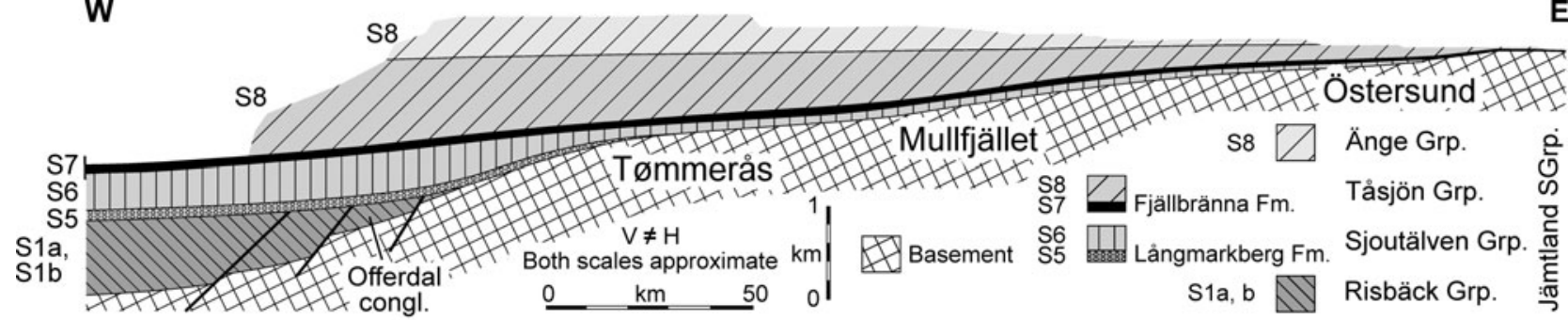

E

Figure 4. Semi-schematic restored profile through the eastern part of the central Scandinavian Caledonides from Gee et al. (1985a) showing the relative restored positions of the Tømmerås and Mullfjället Window-Basement and the Lower and Middle allochthons.

shelf towards Iapetus, deposited directly outboard of the Window-Basement (Fig. 4; Gee, 1978).

\section{3.b. Two-basin model: allochthonous Window-Basement (Model II)}

In Finnmark, Gayer \& Roberts (1973) determined a $35 \mathrm{~km}$ displacement from the NW for the TonianCryogenian sediments (S1b, S2) of the Lower Allochthon because its branch-line overlapped the autochthonous Ediacaran sediments (S6) around Lakselv (Fig. 1). Rhodes (unpub. PhD thesis, University College of Cardiff, Wales, 1976) noted that the restored Lower Allochthon overlay the unconformable Ediacaran cover (S5, S6) on the Komagfjord WindowBasement (Fig. 1) and estimated a c. $15 \mathrm{~km}$ displacement for the Window-Basement from the NW. The Komagfjord Window-Basement was therefore incorporated into the orogen prior to deformation in the Lower Allochthon. Since the Lower Allochthon is continuously exposed from Lakselv to east Finnmark, with no reported major thrusts (Føyn, 1967), the possibility of moving the Lower Allochthon to the hinterland side of the Komagfjord Window-Basement was not considered. Subsequent restorations included shortening of up to $60 \%$ within the Lower Allochthon, and also postulated the presence of two buried Window-Basement units based on large-scale antiformal structures in the Middle Allochthon (Chapman, Gayer \& Williams, 1985; Townsend et al. 1986; Gayer et al. 1987; Rice, 2014). In this model, the Window-Basement formed a palaeo-topographic high separating two sedimentary basins, imbricated into the Middle and Lower allochthons (Fig. 2b).

\section{Orogenic transects}

Only transects where both the Lower Allochthon and the Window-Basement are well developed are useful when considering their inter-relationships. A transect across the Nasafjäll Window, in which the WindowBasement is particularly well documented (Thelander, Bakker \& Nicholson, 1980), is therefore not included; the Lower Allochthon is very poorly developed (Fig. 1). However, Anderson (1989) presented a restoration of the Rombak Window-Basement (Fig. 1) relative to the poorly preserved Lower Allochthon (Rautas Complex) in northern Scandinavia, based on metamorphic criteria.

In all descriptions, the Window-Basement is documented last, to avoid prejudging the conclusions. Much of the lithological, structural and metamorphic data are summarized in Tables 2-5.

\section{4.a. Transect 1: east Finnmark to east Troms}

Transect 1, from eastern Varangerhalvøya to Kvænangen, is c. $325 \mathrm{~km}$ long (Figs 1, 5). All localities are shown in Figure 5.

West of Andabakoaivi, the Autochthon comprises the Torneträsk Formation (S6, <260 m; Føyn, 1967; Thelander, 1982). East of Andabakoaivi, the age of the Autochthonous cover increases down to the

Table 4. Variations in thickness $(\mathrm{km})$ of the stratigraphic units (cf. Table 1) across the transects.

\begin{tabular}{|c|c|c|c|c|c|c|c|c|c|}
\hline & \multirow[b]{3}{*}{ Transect } & \multicolumn{8}{|c|}{ Tectonic units } \\
\hline & & \multicolumn{2}{|c|}{ MA } & \multicolumn{2}{|c|}{ WB } & \multicolumn{2}{|c|}{ LA } & \multicolumn{2}{|c|}{ A } \\
\hline & & Upper & Lower & Upper/ internal & Lower/ external & Internal & External & West & East \\
\hline \multirow[t]{2}{*}{1} & Successions & - & $1 \mathrm{a}, 1 \mathrm{~b}-?$ & - & 1a $/ 5,6$ & $1 b-2$ & $1 \mathrm{~b}-8$ & $5-6$ & $1 \mathrm{~b}$ \\
\hline & Thickness & - & 7.1 & - & $0.19 / 0.20$ & $>2.0$ & 5.0 & $<0.26$ & 0.60 \\
\hline \multirow[t]{2}{*}{2} & Successions & $1 \mathrm{~b}, 2,5,6$ & $1 \mathrm{a}, 1 \mathrm{~b}, ? 5$ & 5,6 & 5,6 & $1 a-2,5-7$ & - & $6-7$ & - \\
\hline & Thickness & 4.5-6 & 1.25 & 0.02 & 0.02 & 1.12 & - & 0.02 & - \\
\hline \multirow[t]{2}{*}{3} & Successions & $1 b, 2,5,6$ & $1 \mathrm{a} / 1 \mathrm{~b}$ & $6-8$ & $6-8$ & $6-8$ & - & 7 & - \\
\hline & Thickness & $4.5-6$ & $>0.3 / 1.2$ & $<0.07$ & $<0.07$ & 1.12 & - & $<0.04$ & - \\
\hline \multirow[t]{2}{*}{4} & Successions & - & $1 \mathrm{a}, 1 \mathrm{~b}, 5-7$ & $? 5-7$ & $5-8$ & $1 a-2,5-6$ & $7-8$ & $7-8$ & $7-8$ \\
\hline & Thickness & - & 4.3 & $<0.3$ & 0.15 & 3.4 & 0.8 & 0.4 & $<2.2$ \\
\hline
\end{tabular}

See text for data sources. 
Table 5. Variation in thrust transport directions across the transects

\begin{tabular}{|c|c|c|c|c|c|c|c|}
\hline \multirow[b]{3}{*}{ Transect } & \multicolumn{7}{|c|}{ Tectonic units } \\
\hline & \multicolumn{2}{|c|}{ MA } & \multicolumn{2}{|c|}{ WB } & \multicolumn{2}{|c|}{ LA } & A \\
\hline & Upper & Lower & Upper/internal & Lower/external & West & East & \\
\hline 1 & SE & $\mathrm{SE}+\mathrm{ESE} / \mathrm{E}$ & - & $\mathrm{SE}$ & ESE/E & $\mathrm{ESE} / \mathrm{E}$ & - \\
\hline 2 & SE & SE & ESE & ESE & ESE/E & - & - \\
\hline 3 & SE & SE & SE & $\mathrm{SE}$ & $\mathrm{ESE} / \mathrm{E}^{*}$ & - & - \\
\hline 4 & SE & SE & SE & SE & SE & SSE & - \\
\hline
\end{tabular}

*Data for the Lower Allochthon on Transect 3 is taken from Transect 2.

Vadsø Group (S1b, c. $600 \mathrm{~m}$ thick; Johnson, Levell \& Siedlecki, 1978). The Autochthon is overlain by the East Finnmark Parautochthon, with the Hanadalen Thrust (base Hanadalen Thrust Sheet) forming the base of the Lower Allochthon (Gaissa Thrust Belt; Rice, 2014; Fig. 5).

The same lithostratigraphy occurs in the East Finnmark Autochthon, East Finnmark Parautochthon and Gaissa Thrust Belt. In east Finnmark, this comprises Tonian-Tremadocian deposits (Vadsø, Ekkerøya and Tanafjord groups, S1b-S2, c. $2.5 \mathrm{~km}$, overlain by the Vestertana and Digermul groups, S3-S8, c. 2.5 km; Johnson, Levell \& Siedlecki, 1978; Føyn \& Siedlecki, 1980; Edwards, 1984; Rice \& Townsend, 1996; Røe, 2003). In the Porsangerfjord area, similar Tonian-Cryogenian deposits occur (Airoaivi, Ekkerøya and Tanafjord groups, S1b-S2; Williams, 1976a, b; Townsend, Rice \& Mackay, 1989; Rice \& Townsend, 1996). The total thickness is unknown due to uncertainties in the Airoaivi Group thickness (S1b), but is likely to be $>2 \mathrm{~km}$.
The predominantly E- to ESE-directed shortening in the Gaissa Thrust Belt increased from $16 \%$ in the Hanadalen Thrust Sheet to $59 \%$ in the Munkavarri Imbricate Zone (Chapman, Gayer \& Williams, 1985; Townsend, 1987; Townsend et al. 1986; Townsend, Rice \& Mackay, 1989; Rice, 2014; Fig. 5). The metamorphic grade increased from lower anchizone - diagenetic zone in the east to epizone - upper anchizone in the west (Rice et al. 1989a).

Although the Middle Allochthon is basementdominated (Kirkland, Daly \& Whitehouse, 2006), the basal unit (Laksefjord Nappe; Fig. 5) comprises $7.1 \mathrm{~km}$ of the Laksefjord Group, with proximally derived basal alluvial-fan conglomerates (Ifjord Formation, S1a, c. $3 \mathrm{~km}$; Chapman, unpub. PhD thesis, University College of Cardiff, Wales, 1980; Føyn, Chapman \& Roberts, 1983).

Caledonian thrusting was predominantly SEdirected in the Kalak Nappe Complex, but E- to ESEdirected movement occurred in the basal mylonites (Townsend, 1987; Rice, 1998). Metamorphism in the

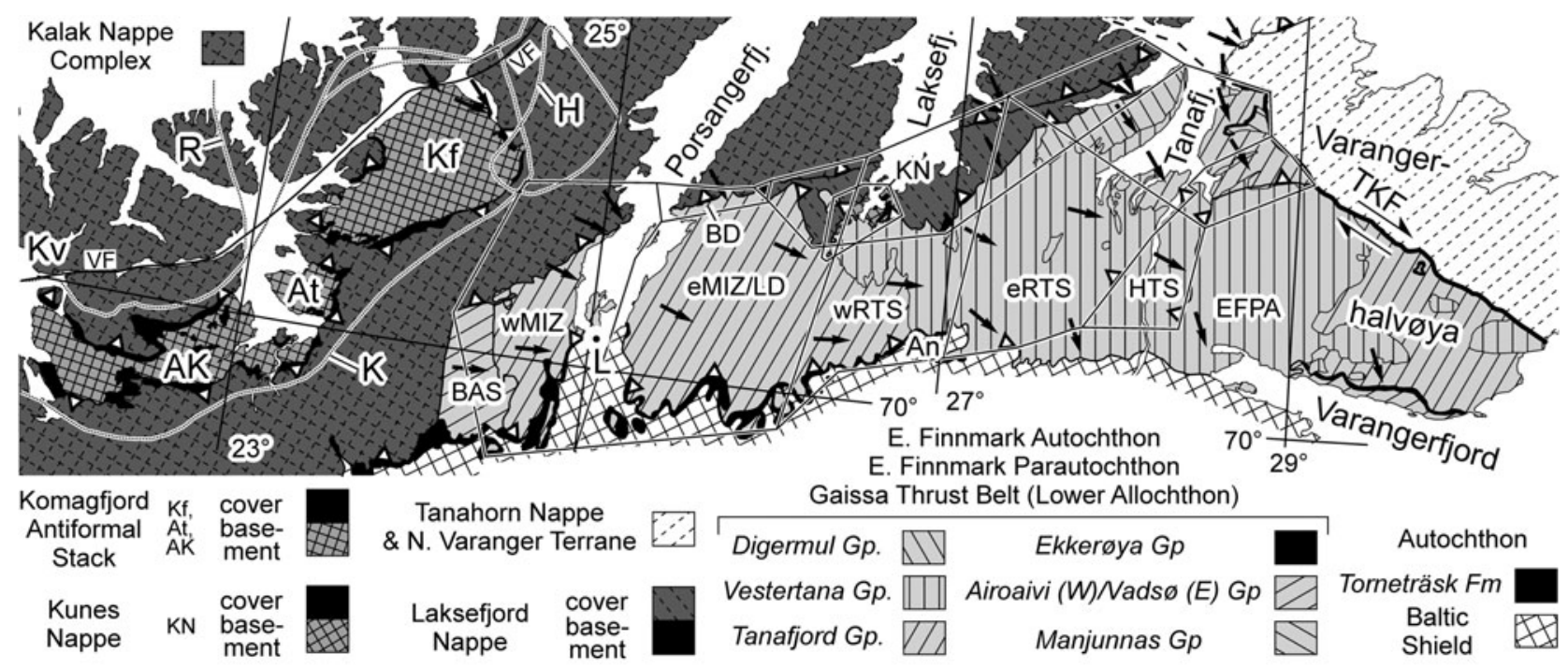

Figure 5. Geological map of the Finnmark Caledonides (Transect 1; Fig. 1). TKF - Trollfjorden-Komagelva Fault; EFPA - East Finnmark Parautochthon; HTS - Hanadalen Thrust Sheet; eRTS - eastern part of Ruoksadas Thrust Sheet; wRTS - western part of Ruoksadas Thrust Sheet; eMIZ/LD - eastern part of Munkavarri Imbricate Zone and Lakkaskaidi Duplex; wMIZ - western part of Munkavarri Imbricate Zone; BAS - Betusordda Antiformal Stack; BD - Børselv Duplex; Kf, At, AK - Komagfjord, Altenes and Alta-Kvænangen tectonic windows; H, R - branch-lines around Hatteras and Revsbotn Basement Horses; K - branch-line around the Komagfjord Antiformal Stack; An - Andabakoaivi; Kv - Kvænangen; L - Lakselv; VF - Vargsund Fault. Arrows indicate thrusting direction. Modified from Rice (2014). 
Laksefjord Nappe reached epizone grade (Rice et al. $1989 b$ ) during SE-directed thrusting (Milton \& Williams, 1981). Later brittle out-of-sequence thrusting may have been E- to ESE-directed (Williams, Milton \& Chapman, 1984; Rice, 2014).

Window-Basement in the (1) Komagfjord, (2) Altenes and (3) Alta-Kvænangen tectonic windows (Fig. 5) is unconformably overlain by (1) the Slettfjell (S5, S6) and Lomvatn formations (?S1b), (2) the Rafsbotn Formation (S5, S6) and (3) the Bossekop (S1b) and Borras (S5, S6) groups, respectively (Føyn, 1985; Pharaoh, 1985). An epizone grade metamorphism occurred during SE-directed thrusting (Rice et al. 1989b; Torgersen \& Viola, 2014). Two other buried WindowBasement units, the Hatteras and Revsbotn Basement Horses, have been postulated, underlying the Middle Allochthon (Chapman, Gayer \& Williams, 1985; Gayer et al. 1987; Fig. 5).

The Kunes Nappe Window-Basement (Fig. 5) comprises basement unconformably overlain by dolomites (S2). These were deformed at lower greenschist facies during SE-directed thrusting, doming the Laksefjord Nappe (Føyn, Chapman \& Roberts, 1983; Rice, 2001).

\section{4.b. Transects 2 and 3: Västerbotten to Nordland and Jämtland to Trøndelag}

These two transects have similar regional geologies (Figs 1, 6). Transect 2, from north of Vilhelmina in Västerbotten to east of Børgefjell in Nordland is $c$. $140 \mathrm{~km}$ long. Transect 3, from north of Östersund in Jämtland to Steinkjer in Nord Trøndelag is $c .205 \mathrm{~km}$ long. When extended to the pre-erosional thrust-front (Hossack \& Cooper, 1986), the transects are c. $120 \&$ $90 \mathrm{~km}$ longer, respectively. All localities are shown in Figure 6.

Both transects are cut by low-angled detachment faults (Fig. 6; Rice, 1999; Osmundsen et al. 2003, 2005; Grimmer et al. 2015; Robinson et al. 2014). These are reviewed in the Discussion (Section 6.f).

The Jämtland Supergroup (c. 1.1-1.7 km thick; Gee et al. 1974, 1985a; Basset, Cherns \& Karis, 1982) forms the Autochthon, Lower Allochthon and cover units in the Window-Basement.

\section{4.b.1. Transect 2: Västerbotten to Nordland}

On Transect 2 (Fig. 6), the Autochthon comprises the Sjoutälven Group (Gärdsjön Formation, S6, <5 m), overlain by the Tåsjön Group (Fjällbränna Formation, S7, <10 m; Gayer \& Greiling, 1989), at diagenetic to lower anchizone metamorphic grades (Warr, Greiling \& Zachrisson, 1996).

In the Lower Allochthon (Blaik Nappe Complex), the Risbäck Group crops out in the east (S1a, b, c. 600 m; S2, 110 m; Fig. 6). The overlying Sjoutälven Group comprises the Långmarkberg $(\mathrm{S} 5,50 \mathrm{~m})$ and Gärdsjön (S6, $280 \mathrm{~m})$ formations, overlain by the Tåsjön Group (Fjällbränna Formation, S7, 80 m; Gayer \& Greiling, 1989; Kumpulainen \& Greiling, 2011). These were deformed by E- to ESE-directed thrusting during anchizone to epizone metamorphism (Gayer \& Greiling, 1989; Bierlein \& Greiling, 1993; Warr, Greiling \& Zachrisson, 1996; Angerer \& Greiling, 2012). Gayer \& Greiling (1989) estimated a bulk 50\% shortening.

The Middle Allochthon crops out (1) above the Lower Allochthon near the Caledonian front; (2) in the Fjällfjäll Window through the Upper Allochthon and (3) around the Børgefjell Window-Basement (Fig. 6). Near the Caledonian front, Greiling (1989) described two units. The lower, the Stalon Nappe Complex, comprises $>250 \mathrm{~m}$ conglomerates (S1a) with large basement-derived clasts, overlain by $>750 \mathrm{~m}$ of sandstones (S1b) (the S1a conglomerates may partly be younger; Greiling, pers. comm. 2016). These are overlain by 'pebbly sandstone', possibly of glacial origin (S5, >250 m; Greiling, 1985; Gayer \& Greiling, 1989). The upper part of the Middle Allochthon consists of the Särv Nappe (see Transect 3) cut by within-plate basalt to mid-ocean-ridge basalt (WPB-MORB) dykes (Greiling et al. 2007).

The lower part of the Middle Allochthon occurs around the Børgefjell Window-Basement (Rainesklumpen and Dearka units) while the upper part (Fjällfjäll Unit) is exposed in the Fjällfjäll Window and above the Rainesklumpen Unit (Zachrisson, 1964, 1969; Greiling, 1985, 1989; Fig. 6).

The Middle Allochthon was affected by SE-directed ductile deformation during upper greenschist to lower amphibolite facies metamorphism (Greiling, 1989).

The Børgefjell Window-Basement consists of two or more thrust sheets (Greiling, 1988, Fig. 6), with thin cover successions of the Långmarkberg Formation (S5, c. $2.5 \mathrm{~m}$ ), Gärdsjön Formation (S6, $16 \mathrm{~m}$ ) and Fjällbränna Formation $(\mathrm{S} 7,>2 \mathrm{~m})$. Both the cover and the directly underlying basement underwent ESE-directed deformation during middle to lower greenschist facies (epizone) metamorphism (Gayer \& Greiling, 1989).

\section{4.b.2. Transect 3: Jämtland to Trøndelag}

On Transect 3 (Fig. 6), the Autochthon comprises the Tåsjön Group (Fjällbränna Formation, S7, 20-40 m; Gee et al. 1985a). Conodont Alteration Index (CAI) values of 3.5-5 suggest a lower anchizone metamorphism (Bergström, 1980). However, comparison of CAI data from the Lower Allochthon (Bergström, 1980), where it can be directly compared with illite crystallinity data (Kisch, 1980), suggests that the equivalent illite crystallinity grade for the CAI from the Autochthon is diagenetic zone. The latter estimate is used, since illite crystallinity has been more widely applied to constrain metamorphic grades in the Scandinavian Caledonides.

Within the Blaik Nappe Complex (Lower Allochthon), the oldest sediments exposed (Gärdsjön Formation, S6, <200 m) crop out at St Grässjön, unconformably overlying allochthonous basement (Sveriges Geologiska Undersökning, 1984; Fig. 6). Elsewhere, the Tåsjön Group (Fjällbränna Formation, S7, $50 \mathrm{~m}$ and Norråker Formation, S8, 200-600 m) is overlain 


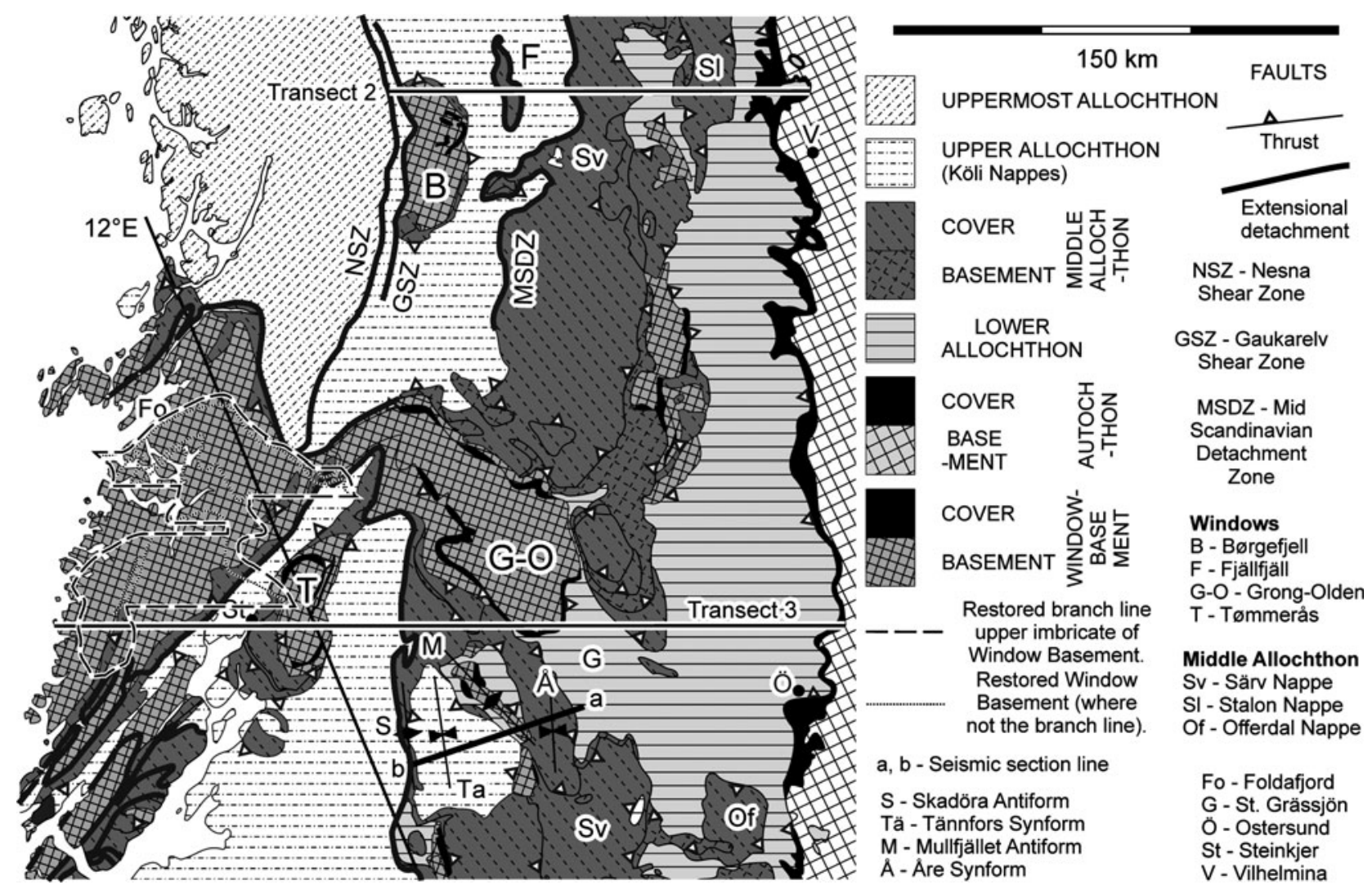

Figure 6. Geological map of the central Scandinavian Caledonides (transects 2 and 3; Fig. 1). Modified from Gee et al. (1985b).

by the Änge Group (S8, 270 m; Gee et al. 1974, 1985a; Basset, Cherns \& Karis, 1982). The maximum known thickness on this transect is therefore up to $1.12 \mathrm{~km}$.

No detailed structural data are available for the Blaik Nappe Complex; the shortening vector and bulk strain from Transect 2 have been assumed (E- to ESE-directed; $50 \%$ shortening). This is supported by the outcrop pattern, which shows pervasive NNEtrending folding (Sveriges Geologiska Undersökning, 1984; more detailed maps are available on line at http://www.sgu.se/). Deformation occurred during diagenetic/lower anchizone metamorphism in the east, rising to epizone grade in the west (Bergström, 1980; Kisch, 1980).

The Middle Allochthon, exposed north and south of the section (Fig. 6), comprises thick imbricates of basement and cover; only the latter are described here. The Offerdal Nappe, the lowest cover thrust sheet, has been divided into three units (Plink-Björklund, Björklund \& Loorents, 2005). The basal part contains proximal, basement-derived alluvial-fan conglomerates $(\mathrm{S} 1 \mathrm{a},>300 \mathrm{~m})$. The overlying units consist predominantly of turbidites and fluvial sandstones (S1b, c. $1.2 \mathrm{~km})$. Gee (1975) correlated these rocks with the Risbäck Group.

The 4.5-6 km thick Tossåsfjället Group in the overlying Särv Nappe (Kumpulainen, 1980) consists of sandstones (Lunndörrsfjällen and Kråkhammeren formations, $\mathrm{S} 1 \mathrm{~b}$, c. $4 \mathrm{~km}$ ) overlain by dolomites (Storån Formation, S2, c. $100 \mathrm{~m}$ ) and then by glacial deposits (Lillfjället Formation, S5, c. $120 \mathrm{~m}$ but maybe $>600 \mathrm{~m}$; Kumpulainen, 2011) and shales, sandstones and con- glomerates (Lövan Formation, S6, c. 1.5-2.0 km). These are cut by abundant WPB-MORB metadolerite dykes (Solyom, Gorbatschev \& Johansson, 1979).

The Lower and Upper Leksdal Nappes, exposed around the Tømmerås Window-Basement, are equivalent to the Offerdal and Särv Nappes (Fig. 6; Gee, 1977; Andréasson, Solyom \& Roberts, 1979). In the Norwegian coastal area, Meakin (1983) recorded a thinned package of the Middle Allochthon, with metadolerite dykes comparable to those in the Särv Nappe (Solyom, Gorbatschev \& Johansson, 1979), complexly infolded with other nappes and the Western Gneiss Region Window-Basement.

The Middle Allochthon was affected by SEdirected deformation during upper greenschist to lower amphibolite facies metamorphism (Andréasson \& Gorbatschev, 1980; Gilotti \& Kumpulainen, 1986; Simpson \& de Paor, 1997).

The Tømmerås and Grong-Olden WindowBasement both contain two major exposed basementcover slices (Fig. 6; Gee, 1980; Roberts, 1989, 1997). The cover successions (Bjørndalen and Grasåmoen formations, S6-S8, <65 m; Andréasson, 1980; Gee, 1980; Roberts \& Stephens, 2000) have been lithostratigraphically correlated with, and were presumed to be direct continuations of, the Autochthon cover succession (Gee, 1975, 1978, 1980; Gee et al. 1985a). The Grong-Olden Window-Basement was affected by middle greenschist facies metamorphism in the east (biotite grade; Johansson, unpub. PhD thesis, University of Lund, 1986) with SE-directed deformation (Sjöström \& Talbot, 1987; Stel, 1988). The Tømmerås 


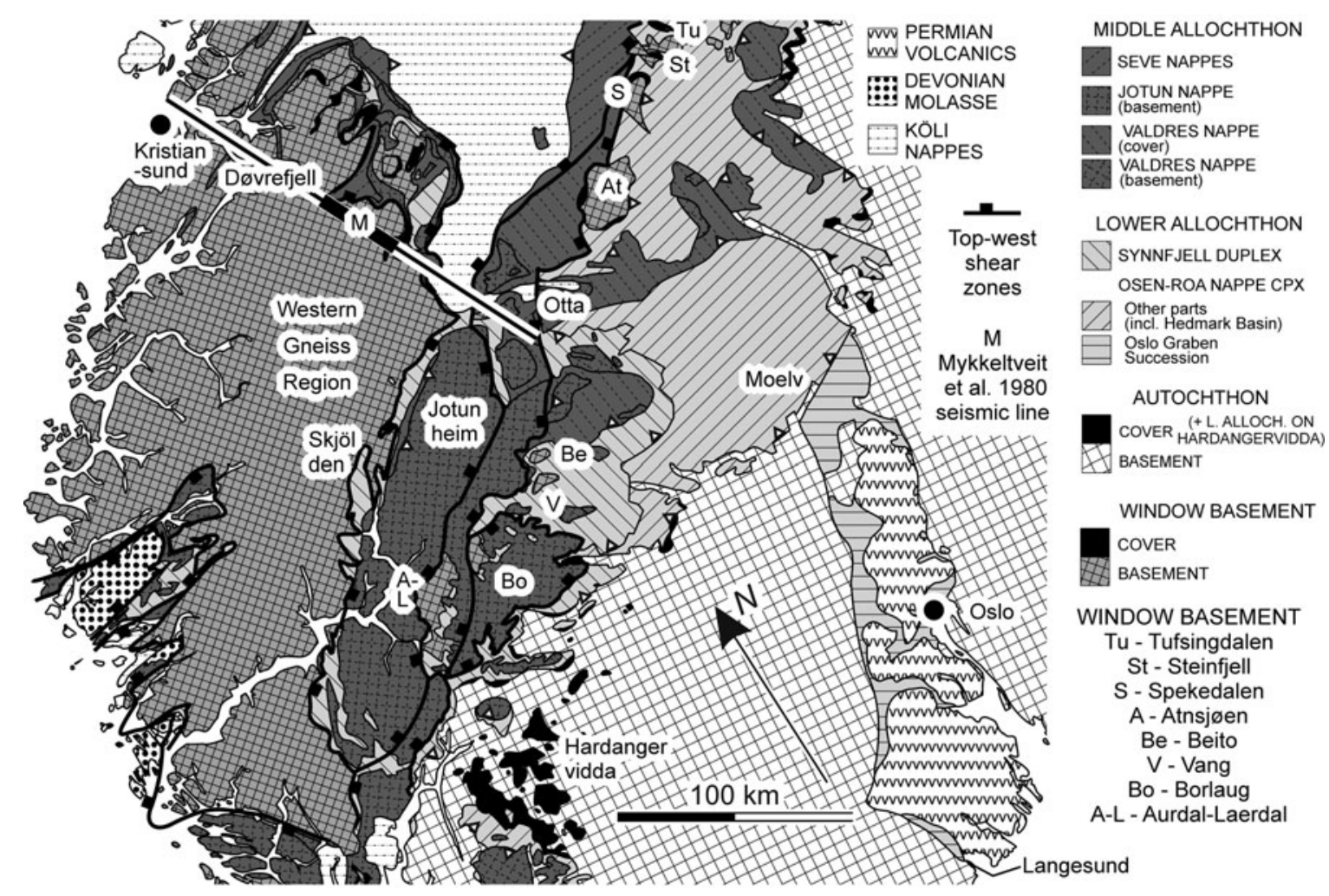

Figure 7. Geological map of the southern Scandinavian Caledonides (Transect 4; Fig. 1). Modified from Gee et al. (1985b).

Windows Basement was affected by SE-directed deformation during middle to upper amphibolite facies metamorphism (Gee, 1980; Lindqvist, 1990).

Near Foldafjord, arkoses/conglomerates lie unconformably on the Vestranden Window-Basement (Fosså Formation, 70 m; Schouenborg, 1989; Fig. 6). As no lithologically diagnostic rocks of the Jämtland Supergroup are present (essentially S5 and S7), correlations are uncertain. The Vestranden Window-Basement was emplaced during SE-directed shortening (Kruhl, 1984) and granulite facies metamorphism (Johansson \& Möller, 1986; Möller, 1988).

Gee $(1975,1978)$ used very simple linear 'branchlines' to infer large thrust-displacements for the nappes along Transect 3. However, no shortening was inferred within the Lower Allochthon and no displacement was proposed for the Window-Basement since the Offerdal Conglomerate, at the base of the Middle Allochthon, was restored to directly west of the present-day outcrop of the Tømmerås Window-Basement (cf. fig 5. in Gee, 1978; Fig. 4). Further, the significance of extension within the middle to upper parts of the orogen was unrecognized (cf. Norton, 1986; Rice, 1999; Osmundsen et al. 2003, 2005; Robinson et al. 2014; Grimmer et al. 2015). Thus the estimated displacements of Gee $(1975,1978)$, which in any event do not incorporate the strain within the rocks under discussion here, are no longer structurally admissible.

\section{4.c. Transect 4: Telemark to Møre og Romsdal}

The branch-line restoration of Transect 4 is constrained by the $c .490 \mathrm{~km}$ long section from Langesund in south- ern Telemark to Kristiansund in west Norway. This line was chosen as it includes the widest and best-studied part of the Lower Allochthon (Bjørlykke et al. 1976; Nystuen, 1981, 1982, 1983, 1987; Bockelie \& Nystuen, 1985; Morley, 1986, 1987a, 1987b). The internal part of the Window-Basement is very complexly deformed (Krill, 1980, 1985; Robinson et al. 2014); a proper restoration of this ductile strain is beyond the scope of the paper. All localities are shown in Figure 7.

On Hardangervidda, the Autochthon comprises undeformed and unmetamorphosed (taken as diagenetic zone alteration) rocks of the Bjørno Member (S7, $<30 \mathrm{~m})$ at the base of the Vidda Group, underlying strongly deformed rocks of the Vidda Group at lower greenschist facies, here presumed to be part of the internal Lower Allochthon (Fig. 7; S7-S8, 400 m; Andresen, 1978, unpub. PhD thesis, University of California; Davis, 1982, pers. comm. 2016; Andresen \& Færseth, 1982). Note that in Figures 1 and 7, both of these units are shown as Autochthon.

At Langesund, the Autochthon consist of $c .1 .1 \mathrm{~km}$ of clastic and carbonate deposits (S7-S8) overlain by the Bruflat Sandstones (S8, 0.5-1 km; Bockelie \& Nystuen, 1985; Worsley et al. 2011).

The Osen-Røa Nappe Complex (Lower Allochthon; Fig. 7) consists of three hangingwall flats linked by ramps (Morley, 1986). The first flat lies in the Alum Shale Formation (S7) overlain by S8 (820 m). The basal thrust cuts $320 \mathrm{~m}$ down-section in the hangingwall at the first ramp to the Moelv Tillite or Ekre Shale (S5 base S6). Along the second ramp it cuts $c .3 \mathrm{~km}$ downsection to the base of the Brøttum Formation ( $\mathrm{S} 1 \mathrm{a} / \mathrm{S} 1 \mathrm{~b}$ ), 
with a pre-S7 thickness of c. $3.4 \mathrm{~km}$ in the Hedmark Basin (Nystuen, 1982; Kumpulainen \& Nystuen, 1985; Morley, 1986).

Thrusting in the Osen-Røa Nappe Complex was SEdirected in the north and SSE-directed in the south (Nystuen, 1981, 1983; Morley, 1986, 1987a, 1987b), with the metamorphic grade changing from epizone grade in the north to diagenetic zone in the south (Bergström, 1980; Robinson \& Bevins, pers. comm. 1986). Shortening dropped from $60 \%$ in the north to c. $0 \%$ in the south, with a bulk shortening of $50 \%$ (Morley, 1986).

The upper part of the Lower Allochthon comprises the Aurdal and Synnfjell Duplexes and the Strondafjord Formation (Hossack, Garton \& Nickelsen, 1985; Fig. 7). The Aurdal Duplex imbricates c. $350 \mathrm{~m}$ of Dalselvi and Ørnberget formations (S6-S8) overlying c. $10 \mathrm{~m}$ of autochthonous shales (S7; Nickelsen, Hossack \& Garton, 1985). The Synnfjell Duplex imbricates $c .410 \mathrm{~m}$ of successions S6-S8. The duplexes were formed during SE-directed shortening, with 63 and $84 \%$ shortening, respectively (Hossack, Garton \& Nickelsen, 1985) at lower- to middle greenschist facies in the Synnfjell Duplex (Nickelsen, Hossack \& Garton, 1985).

The Middle Allochthon comprises the Valdres and overlying Jotun Nappes, with similar cover and basement rocks (Fig. 7). The cover consists of the Valdres Group (S1b, S5, S6, >4 km), including the thick Bygdin and Ormtjernskampen basal conglomerates (S1a; Table 2), overlain by the Mellsenn Group (S6-S7, 250 m; Nickelsen, 1974; Hossack, 1978; Hossack, Garton \& Nickelsen, 1985; Nickelsen, Hossack \& Garton, 1985).

The Valdres and Jotun Nappes are separated by a zone containing ultramafic (serpentinite) to basic nodules, interpreted by Banham, Gibbs \& Hopper (1979) as a Caledonian suture. Rice (2005) took these rocks as evidence for a minor ocean (Fjordane Sea) between the restored Valdres and Jotun Nappes. Andersen et al. (2012) suggested that the 'ophiolitic' material represented a hyper-extended continental margin, separating the restored Valdres and Jotun Nappes.

The Window-Basement comprises the small outcrops of the Tufsingdalen, Steinfjell, Spekedalen, Atnsjøen, Beito, Vang, Borlaug and Aurdal-Lærdal Window-Basement (here together called the External Window-Basement) and the very large Western Gneiss Region Window-Basement (Figs 1, 7). A $<150 \mathrm{~m}$ thick succession (S5-S8) unconformably overlies the Atnsjøen-Spekedalen Window-Basement, affected by NW-SE-oriented deformation, possibly at greenschist facies metamorphic conditions (based on the description of the rocks as phyllites and as having a Caledonian stretching [ductile] lineation; Nystuen \& Ilebekk, 1981; Siedlecka \& Ilebekk, 1982). NW-SE-oriented greenschist facies lineations also occur in the Beito Window (Hossack, 1976), but tectonic contacts in this area may have been affected by relative extension (Andersen, 1998).
The basement in the Western Gneiss Region at Skjølden is comparable to the Fillefjell-Beito Basement Complex (Beito and Vang Window-Basement; Milnes \& Koestler, 1985; Fig. 7). This suggests that the Window-Basement is contiguous between the Western Gneiss Region and the External Window-Basement, under the nappes. Near Døvrefjell, the Gjevilvatnet Group (S5?-S7, <300 m) unconformably overlies basement (Gee, 1980; Robinson et al. 2014); similar cover rocks occur elsewhere within the Western Gneiss Region (Hacker et al. 2003; Andersen et al. 2012). Deformation and metamorphism in the Western Gneiss Region involved burial to ultra-high pressure conditions at its NW margin (Hacker et al. 2003). This was followed by rapid exhumation, involving relative tophinterland deformation between the Western Gneiss Region and the overlying nappes. Two models for this have been presented. (1) In the eduction model (Andersen et al. 1991, 2012), the Western Gneiss Region is autochthonous and exhumation occurred by absolute top-hinterland movement of the overlying nappes. (2) In the buoyancy model, the Western Gneiss Region is allochthonous and exhumation occurred through gravitational forces along the subduction channel, contemporary with orogenic shortening (Hacker et al. 2003; Rice, 2005); top-hinterland movements were only relative to the hangingwall and footwall, not absolute compared to the Baltic Shield.

Seismic studies across the Western Gneiss Region revealed a $4 \mathrm{~km}$ thick low-velocity zone at $14 \mathrm{~km}$ depth (Mykkeltveit, Husebye \& Oftedahl, 1980). This was interpreted as oceanic sediments separating autochthonous crystalline basement from a Laurentia-derived Western Gneiss Region (see Fig. 7 for seismic line). Rice (2005) proposed that the sediments were a relict of the Hedmark Basin (S1a, b and younger), underlying Baltica-derived Window-Basement.

Late-orogenic extension occurred in the area, orthogonal to the thrusting direction in the nappes (Robinson et al. 2014). Most of this, but not all, affected rocks above the structural levels which this paper is concerned with (Fig. 7). Such movement will have resulted in material moving out of the cross-section plane. The assumption here is that the material that moved out was replaced by similar material moving in, such that no significant difference is present.

\section{Alternative restorations}

For each transect, two or more restorations based on the models outlined in Figure 2 are given. These are then evaluated in the Discussion (Section 6). A summary of the restored section lengths and shortening for each restoration is given in Table 6.

\section{5.a. Restoration Transect 1: east Finnmark to east Troms}

The restorations presume a planar basal décollement as far west as the trailing branch-line of the Komagfjord Antiformal Stack or Revsbotn Basement Horse 
Table 6. Summary of restored transects (all lengths and depths in kilometres)

\begin{tabular}{|c|c|c|c|c|c|c|c|c|}
\hline \multirow[b]{2}{*}{ Transect } & \multirow[b]{2}{*}{$\begin{array}{c}\text { Model } \\
\text { (Figs 8-11) }\end{array}$} & \multicolumn{2}{|c|}{ Section length } & \multicolumn{2}{|c|}{ Shortening (\%) } & \multicolumn{2}{|c|}{$\begin{array}{c}\text { Displacement } \\
\text { Window-Basement }\end{array}$} & \multirow[b]{2}{*}{$\begin{array}{l}\text { Maximum depth to } \\
\text { basal décollement }\end{array}$} \\
\hline & & Restored & Deformed & $\begin{array}{l}\text { Over complete } \\
\text { section length }\end{array}$ & $\begin{array}{c}\text { Lower } \\
\text { Allochthon }\end{array}$ & $\begin{array}{l}\text { Trailing } \\
\text { edge }\end{array}$ & $\begin{array}{l}\text { Leading } \\
\text { edge }\end{array}$ & \\
\hline 1 & IA & 491 & 343 & 30 & 51 & 99 & 96 & - \\
\hline 1 & IB & 624 & 343 & 45 & 61 & 99 & 96 & - \\
\hline 2 & IIA & 354 & 262 & 26 & 32 & 85 & 85 & 6.4 \\
\hline 2 & IIB & 416 & 262 & 37 & 32 & 147 & 147 & 6.4 \\
\hline 3 & IA & 372 & 286 & 23 & 43 & 86 & 18 & 14.8 \\
\hline 3 & IB & 397 & 286 & 28 & 46 & 106 & 23 & 11.4 \\
\hline 3 & IIA/III & 448 & 289 & 35 & 40 & 159 & 75 & 9.8 \\
\hline
\end{tabular}

(Window-Basement; cf. Gayer et al. 1987; Fig. 5). The Komagfjord Antiformal Stack and the still-buried Hatteras and Revsbotn Basement Horses must be restored to an internal position relative to this line, a minimum distance of $99 \mathrm{~km}$. Alternatives to this constraint are reviewed in the Discussion in Section 6.b.

For all the models outlined in the following descriptions, restoration of the more internal units (Børselv Duplex, Kunes and Laksefjord Nappes and Kalak Nappe Complex; Fig. 5) essentially follows that given in Rice (2014).

Branch-line restoration of the East Finnmark Parautochthon and Hanadalen and Ruoksadas Thrust Sheets in the Gaissa Thrust Belt moves the trailing branch-line of the Ruoksadas Thrust Sheet $59 \mathrm{~km}$ to the WNW (Rice, 2014). This removes the stratigraphic repetition of the Tanafjord and Ekkerøy groups (S1b, Gaissa Thrust Belt) over the Torneträsk Formation (S6, Autochthon) near Lakselv (Figs 5, 8). Further restorations depend on the model used (Fig. 2).

For Model I, two alternative restorations are given. In Model 1A (Fig. 8a), further in-sequence restoration of the Gaissa Thrust Belt places the trailing branch-line of the eastern Munkavarri Imbricate Zone directly adjacent to the leading branch-line of the Hatteras Basement Horse after it has been restored by the minimum distance of $99 \mathrm{~km}$ (Fig. 8a).

Subsequent restoration of the E- to ESE-directed shortening in the western Munkavarri Imbricate Zone leads to a stratigraphic overlap of the Tanafjord Group (S1b, S2) over the unconformable Window-Basement cover (S5-S6). In the model, this can only be corrected by moving the western Munkavarri Imbricate Zone to W to WNW of the Window-Basement, such that the Window-Basement crops out 'within' the Munkavarri Imbricate Zone (Fig. 8a). The two parts of the Munkavarri Imbricate Zone are separated by a minimum of $c$. $103 \mathrm{~km}$.

During deformation, the western Munkavarri Imbricate Zone must therefore be thrust over the WindowBasement as far as the eastern Munkavarri Imbricate Zone. The total restoration of the trailing branch-line of the eastern Munkavarri Imbricate Zone, from its de- formed position in Porsangerfjord, is $124 \mathrm{~km}$. Thus, after $25 \mathrm{~km}$ of this shortening, ESE-directed displacement of the Window-Basement $(99 \mathrm{~km}$ total displacement) started.

Deformation within the Window-Basement was SE-directed, with c. $3 \mathrm{~km}$ shortening (Gayer et al. 1987; Torgersen \& Viola, 2014). When this displacement occurred is uncertain. If it was directly after SE-directed shortening in the Kalak Nappe Complex and Laksefjord and Kunes Nappes, and hence prior to E- to ESE-directed thrusting, deformation in the western Munkavarri Imbricate Zone would have been out-of-sequence. (Strictly this scenario does not conform to Model I, in which deformation in the Window-Basement starts after the onset of imbrication in the Lower Allochthon.) Conversely, if thrusting was in-sequence, then the SE-directed internal shortening in the Window-Basement represents a short-term change in thrusting direction during the dominant Eto ESE-directed phase of shortening.

In Model 1A, the restored length of the East Finnmark Parautochthon and Gaissa Thrust Belt is $491 \mathrm{~km}$ with the Window-Basement displaced by $99 \mathrm{~km}$ (Fig. 8a). Combined shortening in these units was $51 \%$.

For Model IB (Fig. 8b), in contrast, all the pre-S3 rocks in the Porsangerfjord area (Fig. 5) have been restored to W- to WNW of the Window-Basement, since a division of the Tanafjord Group reflecting the $c .103 \mathrm{~km}$ or more separating the eastern and western Munkavarri Imbricate Zones in Model 1A (Fig. 8a) has not been recognized in the sedimentology (White, 1968, 1969; Roberts, 1974; Tucker, 1976, 1977; Williams, 1976a, $b$ ). This not only requires that the contact between the Tanafjord Group (S1b) and the overlying Vestertana Group (S3, S4) within the western Ruoksadas Thrust Sheet be re-interpreted as a major back-thrust (Figs 5, $8 \mathrm{~b}$ ), but also creates a $>90 \mathrm{~km}$ gap in the restoration between the restored Vestertana Group (S5, S6) of the Ruoksadas Thrust Sheet and the leading edge of the Hatteras Basement Horse (after restoration by $99 \mathrm{~km}$ ). The two parts of the Gaissa Thrust Belt are separated by c. $230 \mathrm{~km}$. 

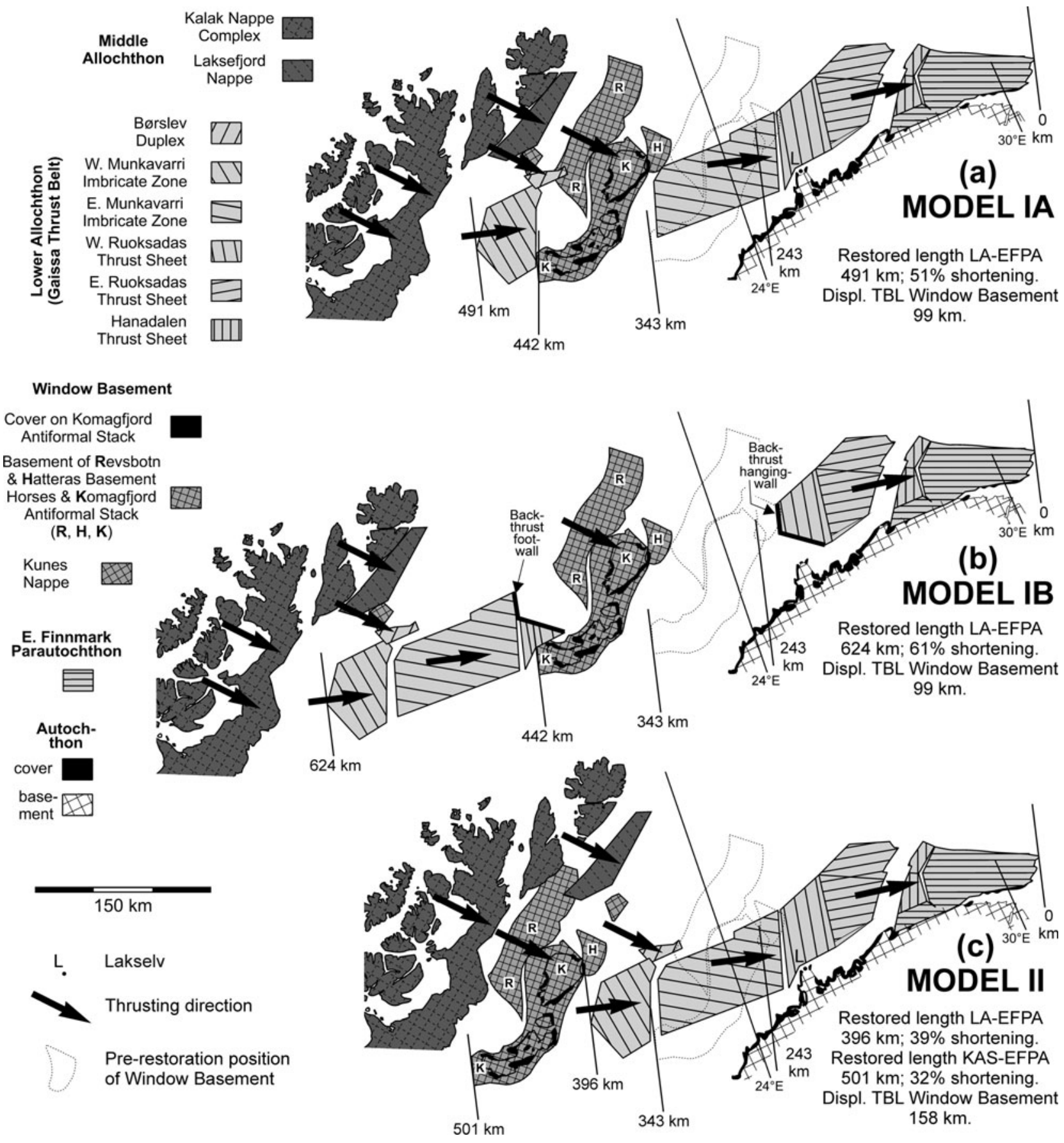

Figure 8. Branch-line restorations based on models I and II for Transect 1 in the north Norwegian Caledonides (Fig. 5; see text for details).

In this model, the Munkavarri Imbricate Zone (both parts) and the low-strain SW part of the Ruoksadas Thrust Sheet are imbricated and thrust over the Window-Basement for $230 \mathrm{~km}$, with a back-thrust sense relative to the hanging wall during at least the last stages of this movement (to under the Vestertana Group in the western part of the Ruoksadas Thrust Sheet). The same arguments for the $3 \mathrm{~km}$ of SE-directed shortening within the Window-Basement documented for Model $1 \mathrm{~A}$ also apply here.

In Model IB, the restored length of the East Finnmark Parautochthon and Gaissa Thrust Belt is $624 \mathrm{~km}$ with the Window-Basement displaced by $99 \mathrm{~km}$ (Fig. 8b).
Combined shortening in these units was $61 \%$. This model more closely follows the definition of Model I (Fig. 2a), as all S1 and S2 rocks were restored to west of the Window-Basement and deformation in the Lower Allochthon started before that in the WindowBasement.

For Model II (Fig. 8c), the Window-Basement, Laksefjord and Kunes Nappes and Kalak Nappe Complex are all pinned to the trailing edge of the Gaissa Thrust Belt and moved towards the hinterland during restoration of all E- to ESE-directed deformation (Rice, 2014). During the final $99 \mathrm{~km}$ of this movement, the WindowBasement moves down its footwall ramp to its restored 
position WNW of the Lower Allochthon. Subsequently, SE-directed thrusting in the Børselv Duplex (Gaissa Thrust Belt), Window-Basement and Kunes and Laksefjord Nappes was sequentially restored (cf. Rice, 2014). No significant gaps are present within the restored section.

In Model II, the restored length of the East Finnmark Parautochthon and Gaissa Thrust Belt is $396 \mathrm{~km}$ (Fig. 8c). Combined shortening in these units was $39 \%$. If the Window-Basement is included, the length is $501 \mathrm{~km}$ with the Window-Basement displaced by $158 \mathrm{~km}$. The overall shortening is $32 \%$.

\section{5.b. Restoration Transect 2: Västerbotten to Nordland}

The dimensions of the Børgefjell Window-Basement in the semi-schematic deformed profile were estimated from inferring a planar basal décollement (except where the restoration subsequently necessitates otherwise; see below) dipping $2^{\circ} \mathrm{WNW}$ (cf. Palm et al. 1991; Fig. 3) and $30^{\circ}$ ramp angles. A horizontal topography was extrapolated westwards from the presentday Caledonian front, which gives an initial thickness of $4.7 \mathrm{~km}$ for the Børgefjell Window-Basement (Fig. 9, section 2.1). A projection of the basement-cover contact below and parallel to the initially inferred basal décollement is taken as the boundary between successions 1a-2 and 5-8 where the former have been deposited.

For the basement rocks of the Autochthon and Window-Basement, vertical and horizontal scales are the same. Cover sediment thicknesses are semischematic; the Risbäck Group is modelled as being $c$. $1.6 \mathrm{~km}$ thick, not $0.7 \mathrm{~km}$, to make it visible on the sections. Thickening of the Window-Basement towards the hinterland is therefore slightly exaggerated in Figure 9, sections 2.5 and 2.6.

Shortening occurred within the Window-Basement (Fig. 6; Greiling, 1988), but this cannot be modelled due to the lack of published data. Including this deformation would increase the restored section lengths.

A $30 \mathrm{~km}$ long buried Autochthonous cover succession (S7 and younger) is extrapolated from the Tåsjön area (Gee, Kumpulianen \& Thelander, 1978) and a preerosion thrust front $c .120 \mathrm{~km}$ east of the present front is assumed (Hossack \& Cooper, 1986; Fig. 9, sections 2.1-2.8). This value has been used, rather than the $c$. $80 \mathrm{~km}$ proposed by Garfunkel \& Greiling (1998) but, as shown later in this section, the actual value chosen makes little difference since the fully restored section length is controlled by the position of the Børgefjell Window-Basement.

Restoration of an inferred bulk shortening of $20 \%$ is needed in the eroded segment of the Lower Allochthon to move the Gärdsjön Formation (S6) in the preserved Lower Allochthon to the west of the $30 \mathrm{~km}$ wide Autochthon (S7) preserved under the nappes (Fig. 9; cf. Gee, Kumpulianen \& Thelander, 1978).

In Model I, the Børgefjell Window-Basement is restored during restoration of the eroded part of the Lower Allochthon. That is, it was imbricated essentially dur- ing the latest phase of thrusting in the Lower Allochthon. The leading edge of the footwall ramp is inferred to be coincident with the trailing edge of the deformed Window-Basement ( $\mathrm{r}$ in Fig. 9, section 2.1), such that there is no overlap of the deformed and restored positions of the Børgefjell Window-Basement. A more easterly position can be used for the footwall ramp, giving an overlap in deformed and restored positions; this results in a thicker Window-Basement block, however (see Fig. 9, sections 2.5-2.8).

Subsequent restoration of the $50 \%$ shortening in the Lower Allochthon (Gayer \& Greiling, 1989) places its trailing edge close to the leading edge of the restored Børgefjell Window-Basement (Fig. 9, section 2.3). To move the Risbäck Formation to the west side of the Børgefjell Window-Basement, required for Model I, a part of the Lower Allochthon has to be moved $44 \mathrm{~km}$ to the WNW (Fig. 9, section 2.4), creating a c. $44 \mathrm{~km}$ wide gap in the section. This is here shown between the leading edge of the preserved Lower Allochthon and the trailing edge of the restored eroded part. Increasing the shortening in the eroded part to $38 \%$ closes this gap (not shown in Fig. 9).

For Model I, the restored section length is $306 \mathrm{~km}$, with a bulk shortening in the Lower Allochthon (including the eroded part) of $42 \%$. The Børgefjell WindowBasement was displaced 27 km (Fig. 9).

In Model II, two possible restorations have been shown, differing only in the restoration of the $62 \mathrm{~km}$ gap in the section between the trailing edge of the Lower Allochthon and the leading edge of the Børgefjell Window-Basement. In both alternatives, restoration of the eroded part of the Lower Allochthon is the same as that for Model I. During subsequent restoration of the preserved part of the Lower Allochthon the Risbäck Group is restored to its final position, forming a step in the basement-cover interface (and hence, later, a ramp in the basal décollement; $r$ in Figure 9, section 2.6) under the present position of the Børgefjell Window-Basement. To fill the space in the deformed section created by this ramp, the Window-Basement must thicken to the west (Fig. 9, section 2.5).

During restoration of the Lower Allochthon, the Børgefjell Window-Basement must be restored to the WNW since, in Model II, imbrication of the WindowBasement occurs prior to shortening in the Lower Allochthon. The same distance $(62 \mathrm{~km})$ must be kept between the trailing edge of the Lower Allochthon and the leading edge of the Window-Basement as seen now in the deformed section (Fig. 9, sections 2.5, 2.6). This implies that any Jämtland Supergroup sediments that lay between the Window-Basement and the preserved Lower Allochthon were thrust over the Lower Allochthon in the footwall of the Middle Allochthon, prior to imbrication of the Børgefjell Window-Basement, and have been eroded away (Fig. 9, sections 2.5, 2.6).

Alternatively, the Lower Allochthon might continue to the west, buried under the structurally higher nappes, as far as the leading edge of the WindowBasement, with $50 \%$ shortening. Restoration of this 


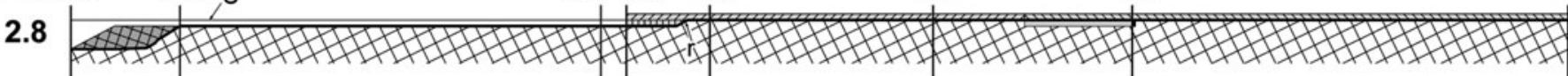
(c) MODEL IIB

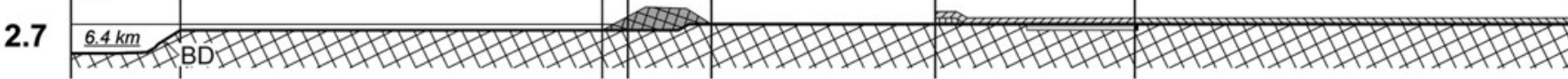

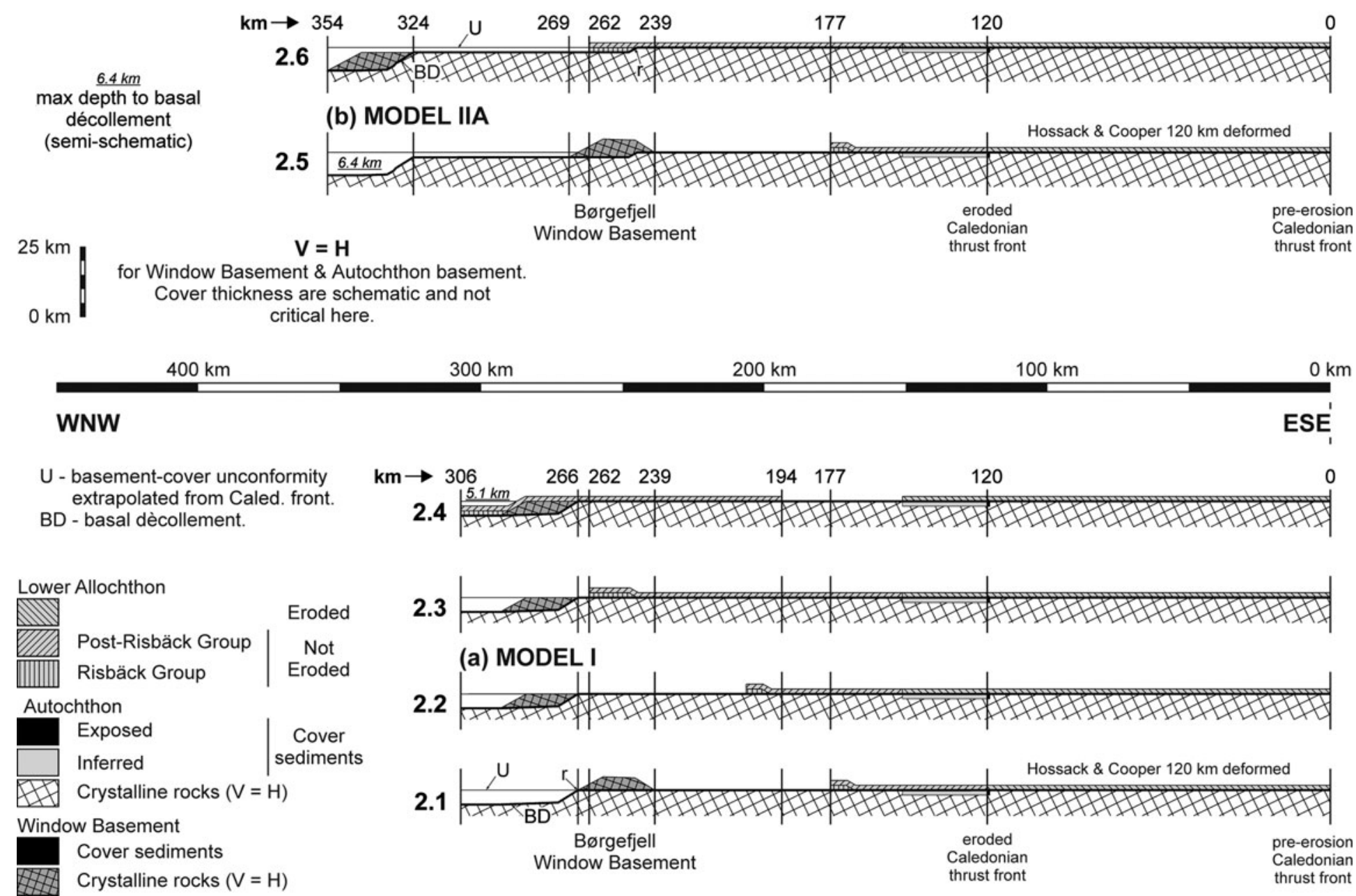


model would move the Børgefjell Window-Basement $124 \mathrm{~km}(2 \times 62 \mathrm{~km})$ to the WNW of the trailing edge of the Lower Allochthon (Fig. 9, sections 2.7, 2.8). In this model the material from this gap, now shortened, still lies buried under the structurally higher nappes.

For Model IIA, the restored section length is $354 \mathrm{~km}$ with a bulk shortening in the Lower Allochthon (including the eroded part) of $32 \%$ (Fig. 9). The Børgefjell Window-Basement was displaced $85 \mathrm{~km}$. For Model IIB, the restored section length is $416 \mathrm{~km}$, with a bulk shortening in the Lower Allochthon (including the eroded part) of $38 \%$. The Børgefjell WindowBasement was displaced $147 \mathrm{~km}$.

\section{5.c. Restoration Transect 3: Jämtland to Trøndelag}

The initial parameters for constructing the deformed section (Fig. 10) are the same as for Transect 2 (first paragraph), except that the eroded part of the Lower Allochthon is $90 \mathrm{~km}$ wide (Hossack \& Cooper, 1986). In all restorations, the eroded part has been restored using the same shortening value $(20 \%)$ as in Transect 2 , giving a displacement of $23 \mathrm{~km}$; this does not move the preserved Lower Allochthon to the hinterland of the $30 \mathrm{~km}$ wide buried Autochthon (Fig. 10) but, since both hangingwall and footwall lie in the Fjällbränna Formation (S7), an absence of stratigraphic overlap is assumed.

The section cuts the lower imbricate of the GrongOlden Window-Basement and both imbricates of the Tømmerås Window-Basement (Fig. 6); lateral continuity between the lower imbricates of these two units has been assumed. Taking a planar basal décollement, the lower imbricate of the Grong-Olden Window-Basement is $3.7 \mathrm{~km}$ thick and of the Tømmerås Window-Basement $6.2 \mathrm{~km}$, linked by an inferred $1.6 \mathrm{~km}$ thick basement slice (Fig. 10, section 3.7, east of kilometre 286 shows this presumed initial geometry). Reducing the thickness of this slice would affect the final modelled thickness of the Window-Basement by a similar amount in Model IA (Fig. 10, sections 3.1, 3.2). A branch-line has been constructed around the upper imbricate and restored to the WNW until it does not overlap the Bjørndalen Formation in the lower imbricate of the Tømmerås Window-Basement, a displacement of $66 \mathrm{~km}$ (Fig. 6).

Two alternative restorations are shown for Model I: one in which the lower imbricate of the Grong-Olden Window-Basement is inferred to be a single slice of basement $3.7 \mathrm{~m}$ thick; and one in which it is inferred to comprise two equally thick basement slices, both overlain by a cover succession (Fig. 10, sections 3.13.4).

In Model IA, the $3.7 \mathrm{~km}$ thick lower imbricate of the Grong-Olden Window-Basement has been restored by the shortest possible amount $(21 \mathrm{~km})$ that keeps the thickness of this part of the unit the same in the deformed and restored sections. (If the footwall ramp were moved to the east, the Window-Basement would thicken dramatically.) This restoration occurred during restoration of the $20 \%$ shortening in the eroded part of the orogen $(23 \mathrm{~km})$; it is therefore modelled as a very late event.

Since the combined lower imbricates of the GrongOlden and Tømmerås Window-Basement presently overlie their restored positions in this model, and the restored upper surface of the Window-Basement (excluding the cover sediments) is kept at the level of the basement-cover interface at the eroded Caledonian front (lines U in Fig. 10), the Window-Basement must thicken westwards. Essentially, the Window-Basement at $\mathrm{x}$ (Fig. 10, section 3.1) restores to $\mathrm{y}$, with the depth to the basal décollement below the planar basement-cover unconformity constrained by the thickness at $\mathrm{x}$ (see $\mathrm{x}^{\prime}$, Fig. 10, section 3.2). As the deformed basement-cover contact at $y$ lies above the restored position, the basement that moves onto y during deformation must be thicker than that at $\mathrm{x}$. This is also the case for the basement at $\mathrm{z}$, moving onto $\mathrm{y}$ (see $\mathrm{x}^{\prime}, \mathrm{y}^{\prime}, \mathrm{z}^{\prime}$ in Fig. 10, section 3.2). The basement wedge therefore thickens gradually to the west with these constraints, until the lower imbricate of the Window-Basement has been fully restored. In the model, the maximum depth of the basal décollement (at the WNW end) is $14.8 \mathrm{~km}$.

West of the restored position of the trailing branchline of the lower imbricate of the Tømmerås WindowBasement, the thickness of the Window-Basement has been kept constant at c. $13 \mathrm{~km}$, until the upper imbricate of the Tømmerås Window-Basement is restored using the branch-line geometry documented above (Fig. 10, section 3.2). As the section line does not cut the branchline around the upper imbricate of the Grong-Olden Window-Basement, a gap is present in all the restorations of this transect between the restored positions of the upper and lower imbricates of the Tømmerås Window-Basement.

For Model IA, the restored section length is $372 \mathrm{~km}$ with $c .21 \mathrm{~km}$ displacement for the lower imbricate of the Tømmerås Window-Basement. Shortening in the Lower Allochthon, including the eroded part, is $42 \%$.

In restoration Model IB (Fig. 10, sections 3.3, 3.4), the lower imbricate of the Grong-Olden WindowBasement is presumed to consist of two equally thick basement slices ( $\mathrm{w}$ and $\mathrm{x}$ ), both with a cover succession. These imbricates restore to $\mathrm{w}^{\prime}$ and $\mathrm{x}^{\prime}$ and together define the length of $y$, which is overlain by the inferred $1.6 \mathrm{~km}$ thick basement slice joining the lower imbricates of the Grong-Olden and Tømmerås Window-Basement. Since the west end of y lies east of the leading edge of the lower imbricate of the Tømmerås Window-Basement, the Window-Basement can retain its original thickness $(1.6 \mathrm{~km})$ rather than thickening (part z). Further, since the trailing edge of $z^{\prime}$ lies west of the trailing edge of the deformed lower imbricate of the Tømmerås Window-Basement (r, Fig. 10, section 3.3), the latter does not thicken significantly more when restored (compare with the position of r relative to the Tømmerås Window-Basement in Figure 10, section 3.1).

In this restoration, the lower imbricate of the Window-Basement does not continue to the west as a thick slice of basement (for example, as thick as at $\mathrm{y}^{\prime}$ ); the upper imbricate of the Tømmerås Window-Basement 


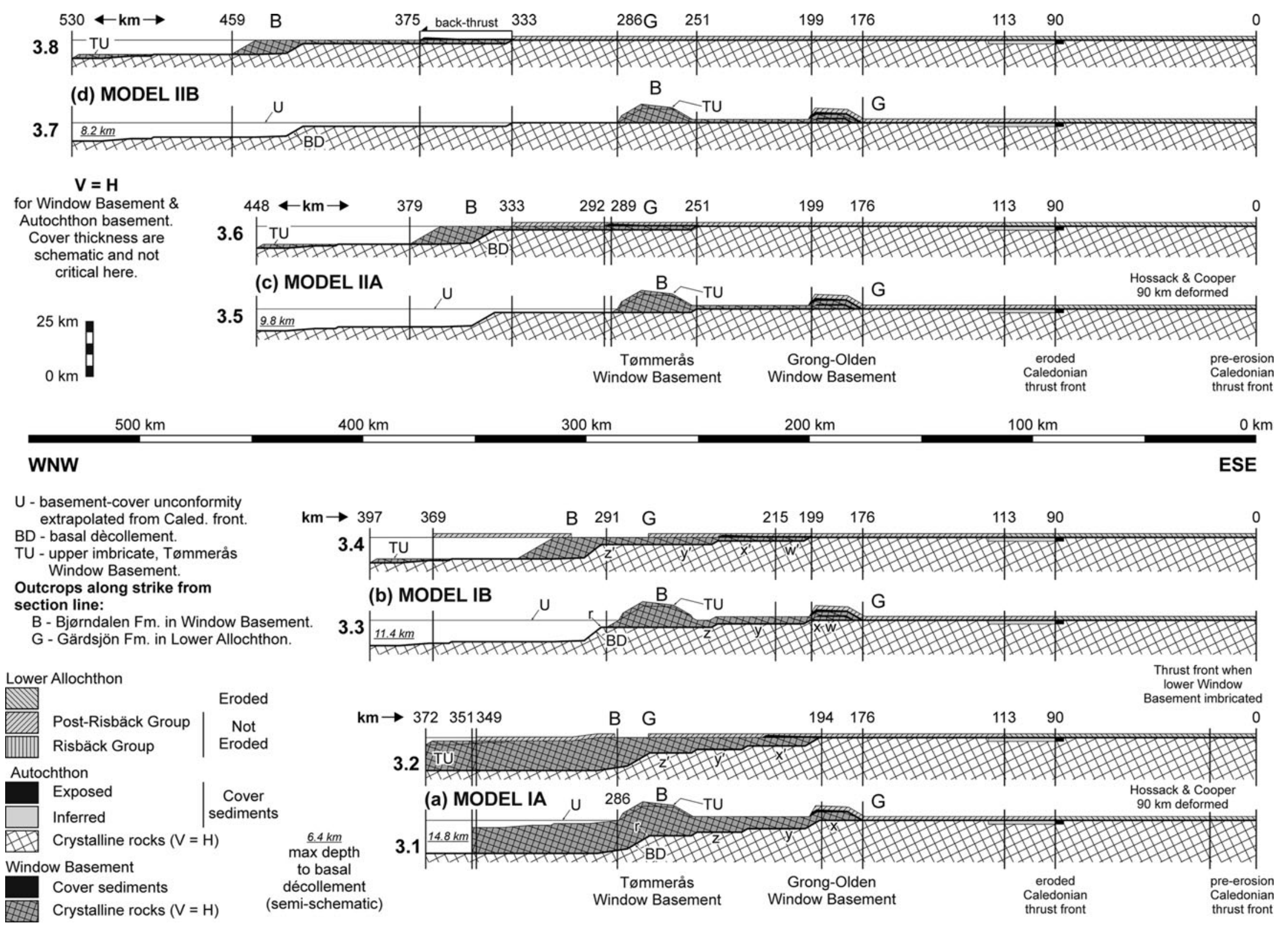

Figure 10. Balanced cross-sections showing restorations based on models I and II for Transect 3 in the central Scandinavian Caledonides (Fig. 6; see text for details). 
is therefore restored to $c .10 \mathrm{~km}$ below the top of the upper imbricate (Fig. 10, section 3.3).

In Model IB, the restored section length is $397 \mathrm{~km}$, with c. $40 \mathrm{~km}$ displacement for the lower imbricate of the Tømmerås Window-Basement. Shortening in the Lower Allochthon, including the eroded part, was $46 \%$.

For both alternatives, it has been assumed that there is no stratigraphic repetition between the restored Lower Allochthon and the Grasåmoen Formation. However, the Gärdsjön Formation crops out directly south of the transect line and this overlaps the Bjørndalen Formation at the southern end of the Tømmerås Window-Basement ( $\mathrm{G}$ and B, Fig. 10, sections 3.1-3.4). If this is taken into consideration, the restored lengths increase to 349 and $369 \mathrm{~km}$, respectively, giving $43 \%$ and $46 \%$ shortening in the Lower Allochthon (including eroded part).

In Model II, restoration of the $20 \%$ shortening in the eroded part and the $50 \%$ shortening in the preserved part of the Lower Allochthon places its trailing edge $333 \mathrm{~km} \mathrm{WNW}$ of the eroded thrust front (Fig. 10, sections 3.6, 3.8). The lower imbricate of the Grong-Olden Window-Basement is presumed to comprise two thin basement-cover sheets.

For Model IIA (Fig. 10, sections 3.5, 3.6) the lower imbricate of the Grong-Olden Window-Basement has been restored to below the restored Lower Allochthon, since it now underlies the deformed Lower Allochthon, to avoid back-thrusting. The most westerly position possible for the Window-Basement is constrained by the $50 \%$ shortening inferred for the Lower Allochthon lying now to the hinterland of the leading edge of the Grong-Olden Window-Basement. In the model, this must be shortened prior to thrusting of the lower imbricate of the Grong-Olden Window-Basement. In Figure 10, section 3.6, the trailing edge of the restored cover of the Grong-Olden Window-Basement (at $292 \mathrm{~km}$ ) must therefore lie by the length of the restored cover $(292-251=41 \mathrm{~km})$ to the foreland of the restored trailing edge of the Lower Allochthon (at $333 \mathrm{~km}$ ). This puts the restored position of the Window-Basement partially under its deformed position and hence the Tømmerås Window-Basement must be thicker than initially drawn (compare thicknesses in Fig. 10, sections 3.5, 3.7). Restoration of the lower imbricate of the WindowBasement places the trailing edge of the Tømmerås Window-Basement $128 \mathrm{~km}$ to the hinterland of the leading edge of the Grong-Olden Window-Basement. The upper imbricate of the Window-Basement is restored by $66 \mathrm{~km}$, using the branch-line geometry in Figure 6; this places the trailing edge of the WindowBasement at $358 \mathrm{~km}$ from the eroded thrust front.

During deformation, the trailing edge of the Lower Allochthon (at $333 \mathrm{~km}$ ) was shortened until it was coincident with the trailing edge of the restored cover on the lower imbricate of the Grong-Olden WindowBasement (at $292 \mathrm{~km}$ ). This started after, but was partly coincident with, the $66 \mathrm{~km}$ emplacement of the upper imbricate of the Window-Basement. As shortening is set at $50 \%$, deformation in the Lower Allochthon during this period progressed towards the leading edge of the cover on the lower imbricate of the Grong-Olden Window-Basement (at $251 \mathrm{~km}$ ). As deformation in the Lower Allochthon reached the leading edge of each of the two minor thrust slices within the lower imbricate of the Grong-Olden Window-Basement, shortening in this lower imbricate occurred. The combined WindowBasement and Lower Allochthon were then transported together, towards the foreland.

For Model IIA, the restored section length is $448 \mathrm{~km}$ with $c .90 \mathrm{~km}$ displacement for the lower imbricate of the Tømmerås Window-Basement. Shortening in the Lower Allochthon, including the eroded part, was $40 \%$.

In Model IIB (Fig. 10, sections 3.7, 3.8), the Window-Basement has been restored completely to the hinterland side of the restored Lower Allochthon. Subsequent restoration of the minor thrust slices in the lower imbricate of the Grong-Olden WindowBasement moves its trailing branch-line $16 \mathrm{~km}$ more towards the hinterland. The upper imbricate of the Window-Basement is restored a further $66 \mathrm{~km}$, using the branch-line restoration in Figure 6.

During thrusting, emplacement of the upper imbricate and shortening within the lower imbricate of the Window-Basement is followed by thrusting of the lower imbricate under the Lower Allochthon, which undergoes $50 \%$ shortening at the same time. The trailing edge of the Lower Allochthon must back-thrust $42 \mathrm{~km}$ relative to the trailing edge of the cover on the Grong-Olden Window-Basement. The amount of backthrusting decreases as imbrication moves towards the foreland.

For Model IIB, the restored section length is $530 \mathrm{~km}$, with $173 \mathrm{~km}$ displacement for the lower imbricate of the Tømmerås Window-Basement. Shortening in the Lower Allochthon, including the eroded part, was $40 \%$, the same as for Model IIA, but includes up to $42 \mathrm{~km}$ of relative back-thrusting on its floor thrust.

\section{5.d. Restoration Transect 4: Telemark to Møre og Romsdal}

The average shortening estimate of $50 \%$ (Morley, 1986) has been used everywhere for restoring imbrication within the Osen-Røa Nappe Complex (Lower Allochthon). No constraints are made for the depth to the basal décollement, although Morley (1986) gave depths for the Osen-Røa Nappe Complex. The similarity of the basement in the Western Gneiss Region and External Window-Basement (Milnes \& Koestler, 1985) indicate that they can be taken as a single unit c. $221 \mathrm{~km}$ wide from NW to SE. No net internal shortening or stretching has been assumed in the WindowBasement (Fig. 11a, b).

In both models, branch-line restoration of the SSEdirected shortening in the Osen-Røa Nappe Complex in the Oslo Graben places its trailing branch-line $c$. $308 \mathrm{~km} \mathrm{NNW}$ of its leading edge, which is coincident with the Autochthon at the south end of the section (Fig. 11a, b). This restoration causes a stratigraphic 
(b) MODEL II

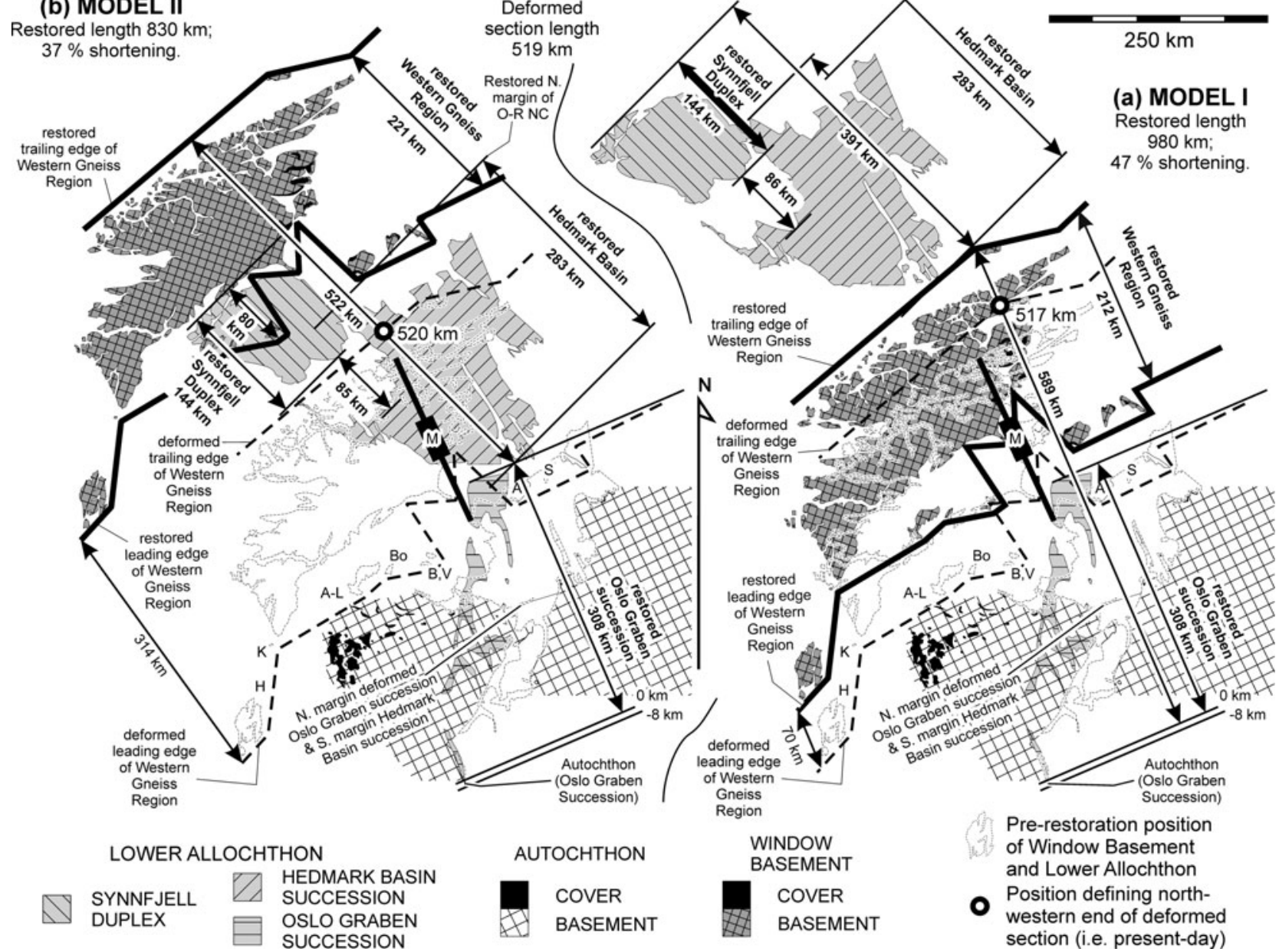

Figure 11. Branch-line restorations based on models I and II for Transect 4 in the south Norwegian Caledonides (Fig. 7; see text for details). External Window-Basement units: A-L - Aurdal-Lærdal; A - Atnsjøen; B - Beito; Bo - Borlaug; H - Haugesund; K Kikedalen. M - Mykkeltveit, Husebye \& Oftedahl (1980) seismic line.

repetition of Moelv Tillite/Ekre Shale (S5, S6) in the Lower Allochthon above S8 in the External WindowBasement cover (Morley, 1986; Nystuen \& Ilebekk, 1981).

In Model I, restoration of the Window-Basement (required by the stratigraphic repetition described earlier in this section) occurs during restoration of the later stages of thrusting in the Lower Allochthon in the Oslo Graben (Fig. 2a). Thrust emplacement of all the Window-Basement must therefore also have been SSEdirected. In Figure 11b, a displacement of $70 \mathrm{~km}$ has been shown for the Window-Basement but, in the absence of a proper balanced section, this is schematic. A minimum value $(c .42 \mathrm{~km})$ is constrained by the trailing branch-line of the restored Oslo Graben part of the Osen-Røa Nappe Complex.

NNW-directed restoration of the Hedmark Basin part of the Osen-Røa Nappe Complex, during restoration of the Oslo Graben part, places the Brøttum Formation (S1a, b and younger; Kumpulainen \& Nystuen, 1985) above the Gjevilvatnet Group and other comparable rocks (S7 and younger) lying unconformably on Døvrefjell (Fig. 4) and many other parts of the Western Gneiss Region (Gee, 1980; Hacker, 2003; Andersen et al. 2012). The Hedmark Basin must therefore be restored to NW of the Western Gneiss Region WindowBasement, a displacement of $281 \mathrm{~km}$, consistent with Model I (Fig. 2a). Restoration of imbrication within the Hedmark Basin gives it a width of $283 \mathrm{~km}$ parallel to the SE-directed thrusting direction (Fig. 11b). The two parts of the Lower Allochthon are separated by $c$. $280 \mathrm{~km}$.

The Synnfjell Duplex (S6-S8) repeats the Hedmark Basin stratigraphy (S1a-S8) and must be restored $86 \mathrm{~km}$ to the NW. Since Hossack, Garton \& Nickelsen (1985) documented $63 \%$ shortening in the southeastern part, but the northwestern part underwent thinning and top-NW extension (Milnes \& Koestler, 1985; Milnes et al. 1997), the 'restored' Synnfjell Duplex is kept the same size as the deformed duplex here (Fig. 11b).

For Model I, the combined length of the restored section is $980 \mathrm{~km}$ with the Window-Basement displaced $70 \mathrm{~km}$. Total shortening in the Osen-Røa Nappe Complex was $66 \%$. The Synnfjell Duplex was not included in the shortening calculation due to its complex deformation history (cf. Krill, 1985; Robinson et al. 2014).

In Model II (Fig. 11a), the Hedmark Basin part of the Osen-Røa Nappe Complex is restored to the NNW 
of the restored Oslo Graben part and then the internal shortening (50\%; Morley, 1986) is restored to the NW, giving a restored width of $283 \mathrm{~km}$. The Synnfjell Duplex is here restored with the same constraints as Model I: an $86 \mathrm{~km}$ offset to the NW relative to the fully restored Hedmark Basin and no net length change.

The amount of NW-directed restoration of the Window-Basement, which was pinned to the trailing edge of the Osen-Roa Nappe Complex relative to the Synnfjell Duplex, depends on the extent of the cover succession preserved on the Window-Basement. Since Andersen et al. (2012) suggest that cover sediments are widespread on the Western Gneiss Region, only those parts of the External Window-Basement without a cover succession are overlain by the Synnfjell Duplex in the restoration (Fig. 11a).

For Model II, the combined length of the restored section is $830 \mathrm{~km}$ with the Window-Basement displaced $314 \mathrm{~km}$. Shortening in the Lower Allochthon was $50 \%$ (as given in Morley, 1986). The Synnfjell Duplex was not included in the shortening calculation due to its complex deformation history (cf. Krill, 1985; Robinson et al. 2014).

\section{Discussion}

The basal thrust of the Window-Basement is, by definition, not exposed. Indirect evidence must, therefore, be used to evaluate which model is more likely correct. The critical question is whether initial deformation in the Window-Basement preceded the onset of deformation in the Tonian-Cryogenian deposits (S1a, b, S2) in the Lower Allochthon or vice versa or, to put it another way, whether the basal thrust of the WindowBasement underlies or overlies the Tonian-Cryogenian sediment of the Lower Allochthon. Seismic data in the central Scandinavian Caledonides (Palm et al. 1991; Fig. 3) was interpreted as supporting Model I. In contrast, Rice (2001) showed that the Kunes Nappe in Finnmark (Fig. 5) was essentially comparable to the Window-Basement and that it clearly overlay the S1b and $\mathrm{S} 2$ sediments in the Lower Allochthon, supporting Model II.

\section{6.a. Restoration techniques}

The balanced cross-sections used (Figs 9, 10) are semischematic with a brittle-style ramp-flat geometry applied to the Window-Basement, although this underwent ductile deformation (e.g. Krill, 1980, 1985; Sjöstrom \& Talbot, 1987; Robinson et al. 2014; Torgersen \& Viola, 2014). This was done to ensure that material was not lost from the sections during restoration. Further, the top-hinterland strain in the Western Gneiss Region and Synnfjell Duplex on Transect 4 (Milnes \& Koestler, 1985; Milnes et al. 1997) has been presumed to cancel earlier top-foreland shortening (Hossack, Garton \& Nickelsen 1985). Although these are important simplifications they have been applied to both models, giving internal consistency for each transect.
In transects 2 and 3, horizontal dimensions from Gee et al. (1985b) were combined with a $2^{\circ}$ planar basal décollement (cf. Palm et al. 1991) to obtain an initial first-order estimate of the thicknesses of the Window-Basement units $(4.7 \mathrm{~km}$ Børgefjell; $6.2 \mathrm{~km}$ Tømmerås lower imbricate, $3.7 \mathrm{~km}$ Grong-Olden lower imbricate). These are underestimates, as a horizontal topography was assumed, but similar to the $6 \mathrm{~km}$ thickness of the complete Müllfjället Window-Basement (Palm et al. 1991; Fig. 3); some restorations indicated that the thickness could be greater (Fig. 10, sections $3.1,3.2$ ), giving a greater depth to décollement. Where multiple imbricates were inferred, comparable to the Bångonåive Window-Basement (Greiling, Gayer \& Stephens, 1993), a shallower depth to décollement develops but the section length increases (Fig. 10, sections 3.3-3.8).

The branch-lines used in restorations of transects 1 , 3 and 4 (Figs 8, 10, 11) are partly based on balanced cross-sections (Morley, 1986; cf. Rice, 2014). Where only the surface outline of a unit was used to define the branch-line, the subsurface ramps will make these larger, but not enough to significantly affect restorations.

\section{6.b. Restoration lengths and displacements}

For Transect 1, the restored lengths of the Lower Allochthon and Window-Basement for models IA and II are similar (Fig. 8a, c; 491 and $501 \mathrm{~km}$, respectively; Table 6). Model IB is longer (624 km), partly because a planar basal décollement was assumed to underlie the deformed Window-Basement (cf. Gayer et al. 1987), forcing a minimum displacement of $99 \mathrm{~km}$ for the Window-Basement. Without this constraint, the length could be reduced by having the footwall ramp directly under the Window-Basement.

On transects 2 and 3, deformation in the WindowBasement was a very late event in Model I (Figs 9, 10) and so the leading edge of the Window-Basement must only be restored by a minor distance to achieve a planar upper surface. With no stratigraphic repetition inferred for most/all of the restored Lower Allochthon and the Window-Basement cover, the former can be partially restored to above the latter, giving shorter restored section lengths than Model II. Only the Risbäck Group (S1a-S2) is older than the Børgefjell Window-Basement cover, and must be restored to the hinterland of the Window-Basement.

Deformation started in the Window-Basement in Model II, and so the leading edge of the WindowBasement is pinned in most cases to the trailing edge of the Lower Allochthon during restoration of the latter (Fig. 9, sections 2.5-2.8 and Fig. 10, sections 3.7 and 3.8). On Transect 3, Model IIA (Fig. 10, sections 3.5, 3.6) however, the leading edge of the GrongOlden Window-Basement is pinned to the immediately overlying Lower Allochthon such that sediments currently lying west of the leading edge have been restored to a similar relative position. Part of the Lower Allochthon, therefore, restores to above the WindowBasement. Nevertheless, thrusting still started in the 
upper imbricate of the Window-Basement before that in the Lower Allochthon in Model IIA. For Model IIB, no overlap of the restored Lower Allochthon onto the Window-Basement is inferred, making this restored section longer than both models I and IIA (Fig. 10, sections 3.7, 3.8).

For Transect 4, Model I is $150 \mathrm{~km}$ longer than Model II (Fig. 11). However, the $70 \mathrm{~km}$ displacement for the Window-Basement in Model I is c. $28 \mathrm{~km}$ longer than the absolute minimum. Further, the partial overlap of the trailing edge of the Synnfjell Duplex and the leading edge of the External Window-Basement, based on the lack of exposed cover on the Window-Basement, also shortens Model II by $80 \mathrm{~km}$ (Fig. 11b). Combining these reduces the difference in restored lengths to c. $40 \mathrm{~km}$, not markedly significant.

Thrust displacement of the trailing edge of the Window-Basement is significantly greater than that of the leading edge only on Transect 3 (Fig. 10), because there are two major Window-Basement imbricates (Fig. 6). Dividing the lower imbricate of the GrongOlden Window-Basement into two thin slices only lengthens the restored sections by $16 \mathrm{~km}(199-215 \mathrm{~km}$; Fig. 10, sections 3.3, 3.4 and the same distance for Fig. 10, sections 3.6 and 3.8).

In summary, displacement of the Window-Basement is always less for Model I than Model II (Table 6), but Model I restorations are not necessarily shorter than those of Model II.

\section{6.c. Constraints on models}

\section{6.c.1. Sedimentological constraints}

All transects have thick basement-derived alluvial-fan deposits at the base of the Middle Allochthon (S1a; Table 2; Nickelsen, 1974; Hossack, 1978; Føyn, Chapman \& Roberts, 1983; Plink-Björklund, Björklund \& Loorents, 2005), indicating a proximal uplifting basement source-area. Gee (1975) correlated the conglomerates of the Offerdal Nappe (Plink-Björklund, Björklund \& Loorents, 2005) with the Risbäck Group but did not show specifically the synsedimentary relationship between the Lower and Middle allochthons. Nystuen \& Kumpulainen (1985) correlated the Tossåsfjället Group with the Offerdal and Risbäck groups, but gave no detailed palaeogeographic model.

In Model I, the basement source-area must have been drowned at the end of the alluvial-fan deposition to allow conglomerate-free deposits to pass through the Lower Allochthon basin into the Middle Allochthon basin (Fig. 2a). In Model II, the basement-high persisted until at least the Gaskiers glaciation (S5; the Alta-Kvænangen Window-Basement is an exception; Føyn, 1985) since diamictites often form the base of the cover succession of the Window-Basement, but it was certainly drowned before/during deposition of the middle Cambrian - Lower Ordovician S7 black shales (Gee, 1980; Siedlecka \& Ilebekk, 1981; Lindqvist, 1984; Pharaoh, 1985; Gayer \& Greiling, 1989; Fig. 2b).
Even then, subsidence was slower than in the adjacent basins, since thicknesses are lower (Table 4).

Palaeocurrents reflecting a northwesterly basement source-area in the Lower Allochthon have only been recorded in Finnmark (Tucker, 1977). Sedimentary structures are poorly preserved within the Risbäck Group along Transect 2 (Greiling, pers. comm., 2016) and the palaeogeography of the Hedmark Basin (NW-SEtrending rift; Nystuen, 1987) make such a distinction invalid. This scarcity is surprising considering the size of the source-area required for the alluvial-fan deposits in the Middle Allochthon.

In Model I on both transects 1 and 4, the Lower Allochthon is restored into two distinct parts, separated by the Window-Basement. There is no sedimentological evidence in either area for such gaps; thicknesses, lithologies and facies are unbroken across the proposed gap, which may be c. $280 \mathrm{~km}$ wide (Figs 8a, b, 11b; Roberts, 1974; Bjørlykke, Elvsborg \& Нøy, 1976; Williams, 1976a, b; Nystuen, 1982, 1987; Bockelie \& Nystuen, 1985; Morley, 1986). Essentially, it was impossible to identify a realistic place where such a division could be made; the divisions used are entirely artificial.

\section{6.c.2. Structural constraints}

Soper et al. (1992) documented a consistent change in thrusting direction: SE-directed in the Middle Allochthon and E- to ESE-directed in the Lower Allochthon, except in southernmost Norway, where it was SE- and SSE-directed. If Model I is correct, evidence of E- to ESE-directed or SSE-directed deformation should be seen in the Window-Basement, similar to that in the external part of the Lower Allochthon; if Model II is correct, SE- and/or E- to ESE-directed lineations should be preserved (Morley, 1986; Townsend, 1987; Gayer \& Greiling, 1989). On transects 1, 3 and 4, deformation in the Window-Basement was SEdirected (Table 5 ; Hossack, 1976; Nystuen \& Ilebekk, 1981; Stel, 1988; Lindqvist, 1990; Torgersen \& Viola, 2014), while on Transect 2 it is E- to ESE-directed (Gayer \& Greiling, 1989). This indicates Model II is applicable. In Transect 1, stretching lineations at the base of the Middle Allochthon preserve the change from SE-directed to E- to ESE-directed movement (Townsend, 1987; Rice, 1998).

Model I divides the Lower Allochthon into two parts on transects 1 and 4. To bring these parts together implies thrusts with displacements of up to $c .280 \mathrm{~km}$ (Figs 8a, b, 11a). No evidence for such thrusts has been found (Føyn, 1967; Nystuen, 1983; Morley, 1986; Townsend, 1987; Gayer et al. 1987). On Transect 1, the inferred thrust for Model IA was placed along Porsangerfjord (Fig. 8a) where exposure is 'poor' despite numerous islands. For Model IB on Transect 1 (Fig. 8b), a back-thrust offset is required along the contact of successions S1b-2 and S3-4. No evidence for this has been found (Føyn, Chapman \& Roberts, 1983). 
Back-thrusting is also inferred for Model IIB on Transect 3 (Fig. 10, sections 3.7, 3.8) between the Lower Allochthon and the Grong-Olden WindowBasement. As there is no field evidence for this, the model is rejected; Ediacaran and younger sediments now lying to the hinterland of the leading edge of the Window-Basement must be restored to a similar relative position.

\section{6.c.3. Metamorphic constraints}

In-sequence thrust sheets within collisional orogens show a general increase in metamorphic grade from foreland to hinterland (Daly, Cliff \& Yardley, 1989), reflecting higher structural levels within the orogen and, therefore, more internal restored positions. Once rocks have been imbricated into the orogen, tectonic burial ceases and erosion of the orogenic wedge, combined with accretion of more units into the footwall, leads to decreasing pressure with subsequent falling temperature (Rice, 1987). Anderson (1989) used across-strike and along-strike metamorphic-grade variations in cover rocks of the Autochthon, the Lower Allochthon (Rautas Complex) and the Windows-Basement to argue for restoration of the Rombak Window-Basement to a position significantly outboard of their equivalents in the Lower Allochthon.

Both out-of-sequence thrusting and synorogenic hinterland directed extension (e.g. Grasemann, Fritz \& Vannay, 1999) can disturb this pattern. The latter process has been documented in the Scandinavian Caledonides at the contact of the Seve (Middle Allochthon) and Köli (Upper Allochthon; Grimmer et al. 2015) nappes. More significantly, the internal parts of the Window-Basement on Transect 4 (and also on Transect 3, in part of the Window-Basement not included here) were subducted to/exhumed from ultrahigh-pressure/high-pressure (UHP/HP) conditions (cf. Möller, 1988; Hacker et al. 2003), disturbing the insequence pattern of metamorphism.

A gradual but irregular increase in metamorphic grade occurs on all transects from the Autochthon (diagenetic zone - lower anchizone) to the internal part of the Lower Allochthon (anchizone - lower/middle greenschist facies; Table 3; Bergström, 1980; Kisch, 1980; Nickelsen, Hossack \& Garton, 1985; Rice et al. 1989a; Warr, Greiling \& Zachrisson, 1996).

In Model I, peak metamorphism in the WindowBasement occurred after that in the internal part of the Lower Allochthon since it was imbricated later, and should have a lower metamorphic grade than the more internally derived overlying Lower Allochthon. However, restoration of the Window-Basement to 'within' (transects 1 and 4) or under (transects 2 and 3) the Lower Allochthon places higher-grade rocks (epizone to eclogite facies) to the foreland of lower-grade rocks of the same orogenic cycle.

In contrast, Model II generally preserves a gradual increase in metamorphic grade from the internal parts of the Lower Allochthon to the lower imbricate or ex- ternal part of the Window-Basement. The only possible exception is on Transect 4, in which the Synnfjell Duplex underwent lower-middle greenschist facies metamorphism (Nickelsen, Hossack \& Garton, 1985) while the External Window-Basement, which underlies the Synnfjell Duplex (Fig. 11), underwent greenschist alteration; further definition of the grade from the published data is not possible (Hossack, 1976; Nystuen \& Ilebekk, 1981; Table 3)

The East Finnmark Autochthon (Vadsø Group) and the Autochthon at Lakselv (Fig. 5) are $>150 \mathrm{~km}$ apart, but the metamorphic grade is diagenetic zone - lower anchizone in both areas (Rice et al. 1989a). Similarly, the Autochthon at Langesund and 150-200 km further north (parallel to the SSE-directed thrusting direction) on Hardangervidda are both diagenetic zone (Fig. 7; Robinson \& Bevins, pers. comm. 1986; Andresen, pers. comm. 2016). Extending this length scale from the eroded thrust-front of Hossack \& Cooper (1986) to transects 2 and 3 indicates that the Autochthon should still be at or below lower anchizone conditions under the eastern part of the Grong-Olden WindowBasement and not much higher under the Børgefjell and lower imbricate of the Tømmerås Window-Basement. The available data indicate grades of epizone-middle greenschist facies (Table 3 ) in these areas, indicating that the Window-Basement has been transported a considerable distance.

\section{6.c.4. Summary of preferred models: models II and III}

The previous sections indicate that in-sequence deformation started in the Window-Basement and subsequently cut down into the Tonian-Cryogenian sediments of the Lower Allochthon.

Model II, by definition, implies imbrication of a sedimentary basin comprising Tonian-Cryogenian sediments (S1a, S1b, S2; Table 1; Fig. 2b) in the Lower Allochthon. The oldest sediments on Transect 3, the Gärdsjön Formation $(<200 \mathrm{~m})$ at St Grässjön, are of Ediacaran (S6) age and these unconformably overlie a slice of allochthonous basement (Fig. 6; Sveriges Geologiska Undersökning, 1984; Gee et al. 1985a). The Jämtland Supergroup on Transect 3 has an S6-S8 thickness of up to $1.12 \mathrm{~km}$ (Gee et al. 1974, 1985a). Assuming $50 \%$ tectonic shortening and, therefore, $100 \%$ thickening, implies a c. $2.2 \mathrm{~km}$ depth to the Caledonian basal décollement under the exposed Lower Allochthon. This is consistent with the geophysical data of Palm et al. (1991) at the eastern side of the Seve Nappes in the Åre Synform (2.4 km depth to décollement; Fig. 3). The preferred restoration for Transect 3 therefore combines the allochthonous Window-Basement status of Model II with the Model I palaeogeography espoused by Gee (1975), in which the Window-Basement lies at the western margin of a shelf overlain by S7 and younger sediments. This is shown as Model III in Figure 2c.

The difference between Model III and that proposed by Gee $(1975,1980)$ partly lies in the restoration of 
the Lower Allochthon. Gee (1975, 1980), like Gayer \& Roberts (1973) in Transect 1, made no attempt to restore the deformation within the external imbricate zone; such methods were not available (cf. Elliot \& Johnson, 1980; McClay \& Price, 1981). Restoration of the shortening within the Lower Allochthon (Gaissa Thrust Belt) in Transect 1, presented at the Uppsala Caledonide Congress in 1981 (Chapman, Gayer \& Williams, 1985), led, from the ensuing stratigraphic overlap, to the realization that the Window-Basement must be far-travelled. The alternative, that the Lower Allochthon was derived from the hinterland of the Window-Basement, was not considered. The lack of stratigraphic overlap between the Lower Allochthon and Window-Basement cover successions in central Scandinavia (Gee, 1975; Gee et al. 1985a) allowed the par-autochthonous Model I to be retained.

\section{6.d. Imbrication of the Lower Allochthon}

The differences between models II and III have consequences for the deformation history. In Model III (Fig. 2c), imbrication of the Ediacaran and younger sediments (S6-S8) deposited above the WindowBasement must have occurred prior to imbrication of the underlying Window-Basement (unless out-ofsequence thrusting is invoked). The base of the Lower Allochthon therefore overlies the Window-Basement. If the displacement due to this early imbrication is minor, the sediments may still partially overlie the Window-Basement, as for the lower imbricate of the Grong-Olden Window-Basement on Transect 3. In Model II (Fig. 2b), imbrication of the WindowBasement occurred prior to thrusting within the Tonian-Cryogenian sediments (S1a, S1b, S2) in the Lower Allochthon. The base of the Lower Allochthon therefore underlies the Window-Basement. In both cases, the Window-Basement can be considered as a separate unit to the Lower Allochthon, either under- or overlying it.

In areas where both Tonian-Cryogenian and Ediacaran-Ordovician sediments occur both above and to the foreland of the Window-Basement on the same transect through the orogen, the deformation sequence is likely to have been complex. By definition, the basal thrust of the Lower Allochthon would underlie the Window-Basement while the roof thrust would lie above it, making the Window-Basement a part of the Lower Allochthon. It is not clear if such an area is preserved within the Scandinavian Caledonides; in areas where Tonian-Cryogenian sediments are preserved in the Lower Allochthon, the sediments younger than those lying unconformably on the Window-Basement were imbricated in the footwall of the Middle Allochthon prior to deformation in either the WindowBasement or the Lower Allochthon. The difference in deformation history could be ascribed to the differing requirements needed to keep a stable critical taper.

If the sediments deposited on the Window-Basement are thrust-transported beyond the leading edge of the
Window-Basement, then no structural evidence of where they were deposited remains. In Transect 3, Model IIA (Fig. 10, sections 3.5 and 3.6) the minimum structural constraint was used to avoid back-thrusting and this is consistent with the metamorphic data. This indicates that sections with Tonian-Cryogenian sediments in the Lower Allochthon are likely to be much more useful in evaluating the Caledonian structural history/restoration of the Window-Basement.

\section{6.e. Basement architecture and the basal décollement}

Two Window-Basement geometries are shown in transects 2 and 3 (Figs 9, 10) although, in all cases, the depth to the Autochthonous basement increases towards the hinterland, with a maximum modelled depth of $14.8 \mathrm{~km}$ (within the constraints of the semischematic models). In Transect 3, Model 1A (Fig. 10, sections 3.1, 3.2), the lower imbricate of the WindowBasement is shown as a thick slice continuing to the west with the upper imbricate derived from above this; in the other models (Fig. 10, sections 3.3-3.8), the lower imbricate thins out immediately west of the restored position of the Window-Basement seen in outcrops and the upper imbricate is restored to directly above the Autochthon. Restorations of Transect 2 follow the latter model (although there is no upper imbricate; Fig. 9, sections 2.1 and 2.2).

These differences partly result from the different internal structures inferred for the lower imbricate of the Grong-Olden Window-Basement. Where this has been left as a single slice of basement (Fig. 10, sections 3.1 and 3.2), thickening (compared to the initial inferred thickness) of the lower Window-Basement imbricate to the west continues to underneath the Tømmerås Window-Basement; where it has been divided into thinner slices, as in the Bångonåive WindowBasement (Greiling, Gayer \& Stephens, 1993; Fig. 10, sections 3.3-3.8), it does not thicken as much. However, for Model IA on Transect 3, the lower imbricate of the Window-Basement could have been drawn to thin down to the level of the basal décollement immediately west of the restored position of the exposed lower imbricate of Tømmerås Window-Basement (at kilometre 286 in Fig. 10, sections 3.1 and 3.2), with the upper imbricate taken as a slice from the Autochthon (as in the other models). Equally, for models IB, IIA and IIB the restored lower imbricate of the Tømmerås WindowBasement (and the Borgefjell Window-Basement on Transect 2) could have been drawn as a thick, buried unit continuing further west than the shown trailing edge. It is in this sense that no definitive reconstruction is shown here; a range of options is provided instead.

If the Window-Basement in Transect 3 is continued westwards as a thick slice, this could be taken as a continuation of the Window-Basement exposed along the Norwegian coast (Vestranden; Figs 1, 6), forming the northern part of the Western Gneiss Region; this is seen in the NW part of the Grong-Olden Window (Roberts, 1989, 1997). The $14.8 \mathrm{~km}$ depth to the basal 
décollement in Model IA (Fig. 8, section 3.1 and 3.2) is comparable to that seismically imaged in the Trøndelag area; much of this thickness is filled by a basement antiformal stack (Hurich et al. 1989). The modelled $11.5 \mathrm{~km}$ thickness of the basement slice is also of the same order of magnitude as the estimated thickness of the Western Gneiss Region Window-Basement ( $c$. 14 km; Mykkeltveit, Husebye \& Oftedahl, 1980).

However, space is required to the hinterland side of the Window-Basement for the deposition of the alluvial-fans of the Offerdal conglomerates (S1a, S1b, $1.5 \mathrm{~km}$; Plink-Björklund, Björklund \& Loorents, 2005) and the $>6 \mathrm{~km}$ thick Tossåsfjället Group (S1b - S6; Kumpulainen, 1980). The sedimentary basin must therefore have deepened somewhere west of the cover sediments on the upper imbricate of the Tømmerås Window-Basement. In a profile across the Western Gneiss Region, Rice (2005) restored the Valdres Nappe (with the Bygdin and Ormtjernskampen S1a conglomerates; Nickelsen, 1974; Hossack, 1978) to NW of the Western Gneiss Region Window-Basement.

\section{6.f. Detachment: footwall-uplift model}

Osmundsen et al. (2003, 2005) proposed that the Børgefjell, Nasafjäll and Rombak Window-Basement areas are wholly autochthonous and formed by footwall-uplift (presumably isostatically controlled) as a result of low- and high-angled normal faulting. Such normal faults trending parallel to the Norwegian coastline occur close to the western margins of these tectonic windows (Fig. 6; Nesna Shear Zone; Gaukarelv Shear Zone; Osmundsen et al. 2003, 2005).

Taking a simplistic approach, the initial constraints used in the balanced cross-sections along Transect 2 indicate that the topographic difference between an isostatically uplifted crest of the Børgefjell WindowBasement and the undisturbed basal décollement dipping at $2^{\circ}$ to the WNW from the Caledonian front (Palm et al. 1991) is c. $4.7 \mathrm{~km}$. As a horizontal topography projecting from the eroded Caledonian thrust-front was used to derive this thickness, this is a minimum value. Isostatic uplift of the Caledonian basal décollement necessitates an equivalent uplift of the crust-mantle boundary. Balancing the added c. $4.7 \mathrm{~km}$ of mantle with loss of overlying continental rocks suggests that $5.5 \mathrm{~km}$ of the Caledonian nappe pile must have been removed, either tectonically or by erosion (using mantle and crust densities of 3300 and $2800 \mathrm{~kg} \mathrm{~m}^{-3}$ ).

Seismic studies show that where major high-angled Mesozoic faults have developed within the Norwegian continental shelf (Lofoten area) the Moho has been uplifted under relatively small-scale blocks, reflecting isostatic re-adjustment (Faleide et al. 2008).

Although there is relatively little onshore seismic data available, Kinck, Husebye \& Larsson (1993) showed that the depth to Moho under the Scandinavian Caledonides increases rapidly from c. $30 \mathrm{~km}$ along the Norwegian coast to $c$. $40-45 \mathrm{~km}$ under the Caledonian front. More recent studies (Ottermöller \& Midzi 2003;
Ebbing, 2007; Kolstrup, Pascal \& Maupin, 2012) have largely confirmed these findings. In detail, the $40 \mathrm{~km}$ Moho depth line passes directly through the Børgefjell, Nasafjäll and Rombak Window-Basement, with the $45 \mathrm{~km}$ depth contour close to the eastern margin of the Børgefjell and Nasafjäll Window-Basement.

Although Osmundsen et al. (2005) indicated that the Komagfjord Window-Basement was not formed as a gneiss-cored dome, the NW margin of the WindowBasement is cut by the $>200 \mathrm{~km}$ long Vargsund Fault, for which a Mesozoic component of movement has been proposed (Fig. 5; Lippard \& Roberts, 1987; Roberts \& Lippard, 2005). Gayer et al. (1987) estimated a throw of $c .600 \mathrm{~m}$ for the Vargsund Fault at the west margin of the Komagfjord Window-Basement. In contrast, no normal faults occur at the NW margins of the inferred Hatteras and Revsbotn Basement Horses in the same area as the Komagfjord Window-Basement, and these remain buried under the Middle Allochthon (Fig. 5; Gayer et al. 1987).

The field evidence (structural and metamorphic) outlined above indicates that the Window-Basement is allochthonous. Seismic data in the central part of the Scandinavian Caledonides has also shown this, and that the underlying basal décollement is essentially planar (Fig. 3; Palm et al. 1991; Juhlin et al. 2016). Equally, data have shown that it is most probable that post-Caledonian extensional faults have modified a preexisting Window-Basement topography; basement imbrication almost certainly also occurred in the areas between the observed Window-Basement, but is not exposed. A combination of processes therefore seems more likely, with initially thrust-developed basement culminations controlling the positioning of late- to post-Caledonian extensional shear-zones that modified and enhanced the doming. In particular, the foliation in the nappes adjacent to the steeply dipping roof-thrusts of the west side of the Window-Basement may have acted as easy-slip horizons, compared to cutting through the Window-Basement. Since the thickness of the Børgefjell Window-Basement used here was derived from a horizontal projection from the eroded Caledonian thrust front at $c .0 .3 \mathrm{~km}$ a.s. 1 and the Børgefjell Window-Basement has an altitude of $c$. $1.5 \mathrm{~km}$, at least $1.2 \mathrm{~km}$ of footwall uplift during late- to post-Caledonian extension can be accommodated by the model presented here.

\section{6.g. Combined palaeogeography}

Figure 12 shows the allochthonous Window-Basement restoration for the four transects superimposed on the geology of the present-day Scandinavian Caledonides, using models II and III. For transects 1 and 4 the complete branch-line restorations for the Lower Allochthon and Window-Basement have been shown, while for transects 2 and 3 only the restored positions of the Window-Basement are shown. Between transects 1 and 2, the Rombak, Bångonaiive and lower imbricate of the Nasafjäll Window-Basement (Andersen, 1989; Bax, 


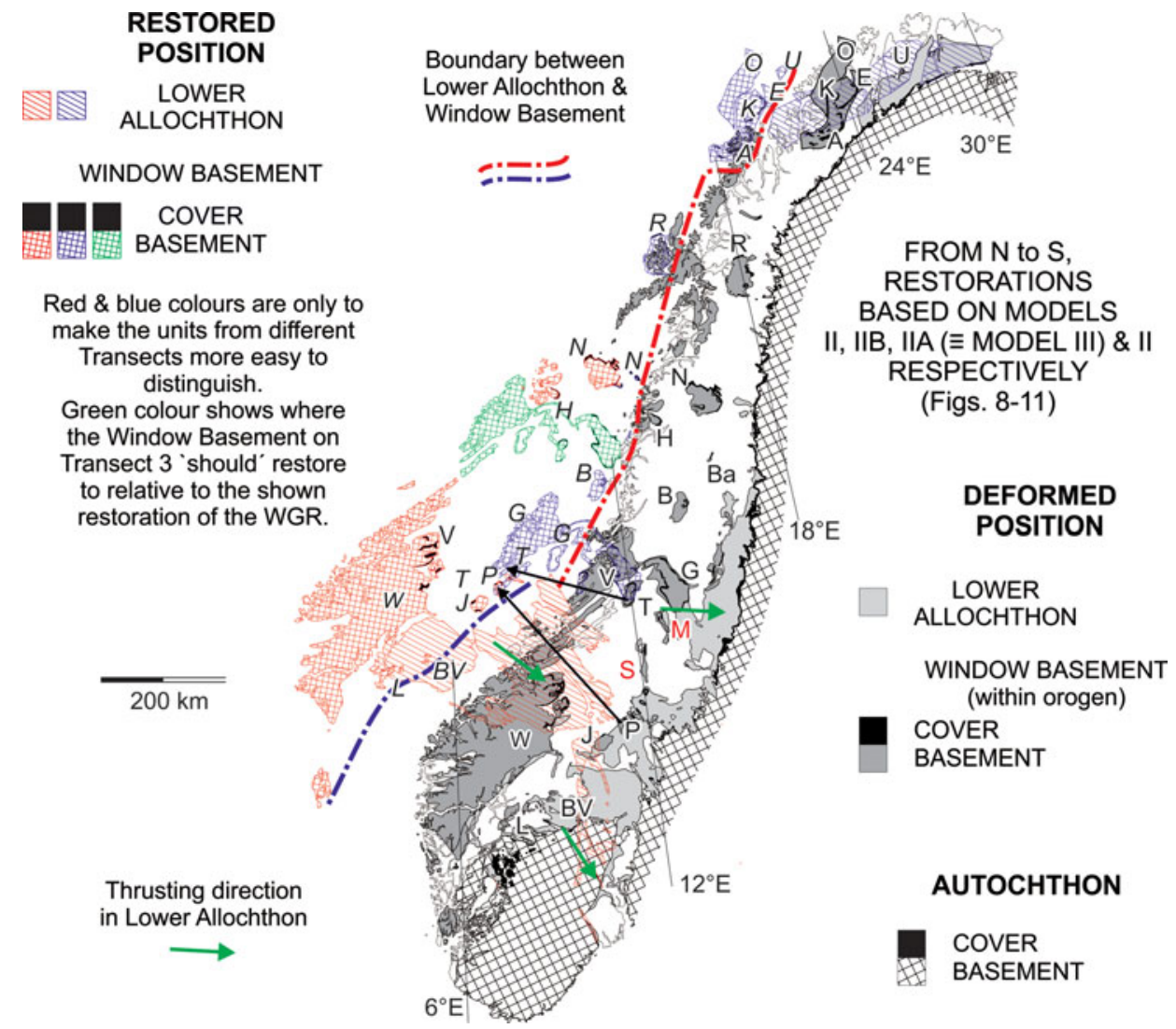

Figure 12. Summary of restorations of the Window-Basement (in red and blue) superimposed on a simplified geology of the Scandinavian Caledonides (from Gee et al. 1985b). The lower imbricate of the Nasafjäll and Rombak Window-Basement units were pinned to the Børgefjell Window-Basement for restoration. The Høgtuva and upper imbricate of the Nasafjäll Window-Basement was restored until no basement-cover overlap occurred with the lower imbricate. The green restoration shows where the Vestranden, Tømmerås and Grong-Olden Window-Basement units should lie with respect to the Western Gneiss Region Window-Basement, based on their present-day relative positions.

1989; Thelander, Bakker \& Nicholson, 1980; Greiling, Gayer \& Stephens, 1993) have been restored by the same amount as the Børgefjell Window-Basement (essentially pinned together). The upper imbricate of the Nasafjäll Window-Basement (Thelander, Bakker \& Nicholson, 1980) and the Høgtuva Window-Basement (Lindqvist, 1990) have been pinned and restored by the minimum amount to remove the basement-cover overlap in the Nasafjäll Window-Basement.

For transects $1-3$, where the thrusting directions within the orogen are parallel and an early SE-directed shortening was followed by E- to ESE-directed shortening (Soper et al. 1992), this restoration gives an eastern margin to the restored Window-Basement that lies close to the Norwegian coastline (Fig. 12).

Similarly in the south, the leading edge of the External Window-Basement delineates a boundary between the Lower Allochthon and Window-Basement that lies c. $100 \mathrm{~km}$ offshore (Fig. 12).

Joining these lines presents major problems, however, not only because the restored Window-Basement of transects 3 and 4 overlap, but also because there is no space in the restoration for either the Mullfjället or Sylarna Window-Basement, several smaller WindowBasement units and the Vemdalen Nappe (Lower Allochthon) between transects 3 and 4 (Fig. 1). In their restored positions the Tømmerås and Spekedalen Window-Basement are essentially adjacent, while in the deformed position they lie close to $180 \mathrm{~km}$ apart.

The failure of the restored segments of transects 3 and 4 to link together poses a major problem in understanding the pre-orogenic palaeogeography of Baltica. This is due to the SE- and SSE-directed transport directions recorded within the Lower Allochthon on Transect 4 (Morley, 1986) compared to the E- to ESE-directed shortening in the Lower Allochthon elsewhere (e.g. Townsend, 1987; Gayer \& Greiling, 1989). The nature of the boundary between the E- to ESEdirected and SE- and SSE-directed shortening areas of the Lower Allochthon is currently unknown.

\section{Conclusions}

1. Four transects across the Scandinavian Caledonides (Finnmark-Troms, Västerbotten-Nordland, Jämtland-Trøndelag, Telemark-Møre og Romsdal) have been restored using a combination of balanced cross-sections and branch-line maps.

2. Each transect is different in detail. Transect 1 has a Lower Allochthon basal décollement in upper Ediacaran - lower Cambrian sediments (S6), while in transects 2-4 the middle Cambrian - lower Ordovician 
'Alum Shales' (S7) is an easy-slip horizon. Transects 1, 2 and 4 have Tonian-Cryogenian basins in the Lower Allochthon, while Transect 3 has only Ediacaran and younger sediments. Transects 3 and 4 underwent (ultra)-high-pressure metamorphism along the internal margin of the Window-Basement. There is, therefore, no transect or area that can be taken geologically as 'typical' of the external part of the Scandinavian Caledonides.

3. On transects 1 and 4, Model I results in the Lower Allochthon being divided into two parts separated by up to $280 \mathrm{~km}$; no sedimentological or structural data have been found for such divisions.

4. Thrusting in Model II shows a gradual swing from SE-directed in the hinterland to E- to ESE-directed in the foreland on transects $1-3$, and from SE-directed to SSE-directed on Transect 4. In Model I, thrusting directions show complex changes when the WindowBasement is accreted into the orogen.

5. The lack of Tonian-Cryogenian sediments on Transect 3, reflecting a different lower - middle Neoproterozoic basin geometry along the Baltoscandian continental margin, makes this profile less reliable for establishing the relationships between the Lower Allochthon and the Window-Basement. Model III is proposed for this transect: allochthonous WindowBasement with no pre-Ediacaran basin in the Lower Allochthon.

6. Despite the along-strike variability in geology, the four transects all suggest that Model II (or III) is more likely correct and can be applied along the whole orogen. However, there remain considerable unsolved problems in linking the restorations of transects 3 and 4 .

Acknowledgements. AHNR thanks Christa \& Rhian Hofmann for 24 years of help in the field and Arild \& Jorunn Pettersen for hospitality in Finnmark during most of that time. AHNR received no grant or financial support from any funding agency of any form whatsoever for this work, which was partly undertaken at University College, Galway, Ireland and at Ruprecht-Karls Universität, Heidelberg, Germany, and completed while at the University of Vienna, Austria. MA thanks Plymouth University for funding numerous undergraduate mapping projects in northern Norway and Sweden which facilitated the fieldwork used to develop this work. We thank Arild Andresen for further information of his research on Hardangervidda, Kateřina Schöpfer for details about the development of the Norwegian continental margin, Per Terje Osmundsen for information about extensional faulting in the Caledonides and Bruno Meurers for discussions about the Moho. Reinhard Greiling and David Gee are thanked not only for their helpful reviews but also for answering subsequent calls for clarification and further information. The editor, Dennis Brown, is thanked for his work on the manuscript.

\section{References}

ANDERSEN, T. B. 1998. Extensional tectonics in the Caledonides of southern Norway, an overview. Tectonophysics 285, 333-51.

ANDERSEN, T. B., CORFu, F., LABRousSe, L. \& OSMUNDSEN, P.-T. 2012. Evidence for hyperextension along the pre-
Caledonian margin of Baltica. Journal of the Geological Society, London 169, 601-12.

Andersen, T. B., Jamtveit, B., Dewey, J. F. \& Swensson, E. 1991. Subduction and eduction of continental crust: major mechanisms during continent-continent collision and orogenic extensional collapse, a model based on the south Norwegian Caledonides. Terra Nova 3, 303-10.

ANDERSON, M. W. 1989. Basement-cover evolution during Caledonian orogenesis, Troms, N Norway. In The Caledonide Geology of Scandinavia (ed. R. A. Gayer), pp. 101-10. London: Graham \& Trotman.

ANDRÉASSON, P.-G. 1980. Metamorphism in the Tømmerås area, central Scandinavian Caledonides. Geologiska Föreningens $i$ Stockholm Förhandlingar 101, 273-90.

ANDRÉASSON, P.-G. \& GORBATSCHEV, R. 1980. Metamorphism in the Tømmerås area, central Scandinavian Caledonides. Geologiska Föreningens i Stockholm Förhandlingar 101, 335-57.

AndrÉASSON, P.-G., Solyom, Z. \& Roberts, D. 1979. Petrochemistry and tectonic significance of basic and alkaline-ultrabasic dykes in the Leksdal Nappe, Northern Trondheim Region, Norway. Norges Geologiske Undersøkelse 348, 47-72.

ANDRESEN, A. 1978. Lithostratigraphy of the Autochthonous/parautochthonous Lower Palaeozoic metasediments on Hardangervidda, South Norway. Norges Geologiske Undersøkelse 338, 59-69.

ANDRESEN, A. \& FÆRSETH, R. 1982. An evolutionary model for the southwest Norwegian Caledonides. American Journal of Science 282, 756-82.

Angerer, T. \& Greiling, R. O. 2012. Fabric evolution at basement-cover interfaces in a fold-and-thrust belt and implications for décollement tectonics (Autochthon, Lower Allochthon, central Scandinavian Caledonides). International Journal of Earth Sciences 101, 1763-88.

BANHAM, P. H., GibBS, A. D. \& HoPPER, F. W. M. 1979. Geological evidence in favour of a Jotunheimen Caledonian suture. Nature 277, 289-91.

Basset, M. G., Cherns, L. \& Karis, L. 1982. The Röde Formation: an early Old Red Sandstone facies in the Silurian of Jämtland, Sweden. Sveriges Geologiska Undersökning C793, 1-24.

BAX, G. 1989. Caledonian structural evolution and tectonostratigraphy in the Rombak-Sjangeli Window and its covering sequences, northern Scandinavian Caledonides. Norges Geologiske Undersøkelse Bulletin 415, 87-104.

BergströM, S. M. 1980. Conodonts as palaeotemperature tools in Ordovician rocks of the Caledonides and adjacent areas in Scandinavia and the British Isles. Geologiska Föreningens $i$ Stockholm Förhandlingar 102, 377-92.

BiERLEIN, F. P. \& GREILING, R. O. 1993. New constraints on the basal sole thrust at the eastern Caledonian margin in northern Sweden. Geologiska Föreningens i Stockholm Förhandlingar 115, 109-16.

BJÖRKLUND, L. J. O. 1987. Basement-cover relationships and regional correlations of the Caledonian nappes, eastern Hinnøy, N. Norway. Norsk Geologisk Tidsskrift 67, 314.

BjørlykKe, K., Elvsborg, A. \& Høy, T. 1976. Late Precambrian sedimentation in the central sparagmite basin of south Norway. Norsk Geologsik Tidsskrift 56, 233-90.

BocKELIE, J. F. \& NYSTUEN, J. P. 1985. The southeastern part of the Scandinavian Caledonides. In The Caledonide Orogen - Scandinavia and Related Areas (eds D. G. Gee \& B. A. Sturt), pp. 69-88. Chichester: Wiley. 
Bowring, S., Myrow, P., LANDing, E., RAmezani, J. \& GROTZINGER, J. 2003. Geochronological constraints on terminal Neoproterozoic events and the rise of metazoans. Geophysical Research Abstracts 5, 13219.

Brown, B. R. \& Wells, M. K. 1966. A contribution to the geology of the Vasijaure-Sjangeli area of Swedish Lapland. Geologiska Föreningen i Stockholm Förhandlingar 87, 527-47.

ChAPMAN, T. J., GAYER, R. A. \& Williams, G. D. 1985. Structural cross-sections through the Finnmark Caledonides and timing of the Finnmarkian event. In The Caledonide Orogen - Scandinavia and Related Areas (eds D. G. Gee \& B. A. Sturt), pp. 593-610. Chichester: Wiley.

Corfu, F., Andersen, T. B. \& Gasser, D. 2014. The Scandinavian Caledonides: main features, conceptual advances and critical questions. In New Perspectives on the Caledonides of Scandinavia and Related Areas (eds F. Corfu, D. Gasser \& D. M. Chew), pp. 9-43. Geological Society of London, Special Publication no. 390.

DAlY, J. S., ClifF, R. A. \& YARDLEY, B. W. D. (eds) 1989. Evolution of Metamorphic Belts. Geological Society of London, Special Publication no 43. Blackwell Scientific Publications, Oxford. 566 pp.

Dyrelius, D., Gee, D. G., Gorbatschev, R., RamberG, H. \& ZACHRISSON, E. 1980. A profile through the central Scandinavian Caledonides. Tectonophysics 69, 247-84.

EBBING, J. 2007. Isostatic density modelling explains the missing root of the Scandes. Norwegian Journal of Geo$\log y 87,13-20$.

EDWARDS, M. B. 1984. Sedimentology of the Upper Proterozoic glacial record, Vestertana Group, Finnmark, North Norway. Norges Geologiske Undersøkelse 394, 1-76.

ELLIOT, D. \& JOHNSON, M. R. W. 1980. The structural evolution of the northern part of the Moine Thrust Zone. Transactions of the Royal Society of Edinburgh: Earth Sciences 71, 69-96.

Faleide, J. I., Tsikalas, F., BreiviK, A. J., Mjelde, R., RitZMANN, O., ENGEN, Ø., WiLSON, J. \& ELDHOLM, O. 2008. Structure and evolution of the continental margin off Norway and the Barents Sea. Episodes 31, 82-91.

FARETH, E. 1979. Geology of the Altenes area, AltaKvænangen Window, North Norway. Norges Geologisk Undersøkelse 351, 13-30.

FøYN, S. 1967. Dividal-gruppen ('Hyolithus-sonen') I Finnmark og dens forhold til de eokambriske-kambriske formasjoner. Norges Geologiske Undersøkelse 249, 184

FøYN, S. 1985. The Late Precambrian in northern Scandinavia. In The Caledonide Orogen - Scandinavia and Related Areas (eds D. G. Gee \& B. A. Sturt), pp. 23346. Chichester: Wiley.

Føyn, S., CHAPMAN, T. J. \& RoBERTS, D. 1983. Adamsfjord og Ul'lugaissa. Beskrivelse til de berggrunnsgeologiske kart 2135 I og 2135 II - M 1:50,000. Norges Geologiske Undersøkelse 381, 1-78.

FøYN, S. \& SIEDLECKI, S. 1980. Glacial stadials and interstadials in the Late Precambrian Smalfjord Tillite on Laksefjordvidda, Finnmark, North Norway. Norges Geologiske Undersøkelse 358, 31-45.

GARFUNKEL, Z. \& GREILING, R. O. 1998. A thin orogenic wedge upon thick foreland lithosphere and the missing foreland basin. Geologische Rundschau 87, 314-25.

GAYER, R. A. \& GreILING, R. O. 1989. Caledonian nappe geometry in north-central Sweden and basin evolution on the Baltoscandian margin. Geological Magazine 126, 499-513.
Gayer, R. A., Rice, A. H. N., Roberts, D., Townsend, C. \& Welbon, A. 1987. Restoration of the Caledonian Baltoscandian margin from balanced cross-sections: the problem of excess continental crust. Transactions of the Royal Society of Edinburgh: Earth Sciences 78, 197217.

GAYER, R. A. \& RoBERTS, J. D. 1973. Stratigraphic review of the Finnmark Caledonides with possible tectonic implications. Proceedings of the Geologist's Association 84, 405-28.

GEE, D. G. 1975. A tectonic model for the central part of the Scandinavian Caledonides. American Journal of Science 275, 468-515.

GEE, D. G. 1977. Extension of the Offerdal and Särv Nappes and Seve Supergroup into northern Trøndelag. Norsk Geologisk Tidsskrift 47, 163-70.

GEE, D. G. 1978. Nappe displacement in the Scandinavian Caledonides. Tectonophysics 47, 393-419.

GEE, D. G. 1980. Basement-cover relationships in the central Scandinavian Caledonides. Geologiska Föreningens $i$ Stockholm Förhandlingar 102, 455-74.

Gee, D. G., Fossen, H., Henriksen, N. \& Higgins, A. K. 2008. From the Early Palaeozoic platforms of Baltica and Laurentia to the Caledonide Orogen of Scandinavia and Greenland. Episodes 31, 44-51.

Gee, D. G., Gezou, J.-C., Roberts, D. \& WolfF, F. C. 1985a. The central-southern part of the Scandinavian Caledonides. In The Caledonide Orogen - Scandinavia and Related Areas (eds D. G. Gee \& B. A. Sturt), pp. 135-62. Chichester: Wiley.

Gee, D. G., Karis, L., Kumpulainen, R. \& Thelander, T. 1974. A summary of Caledonian front stratigraphy, northern Jämtland/southern Västerbotten, central Swedish Caledonides. Geologiska Föreningens $i$ Stockholm Förhandlingar 96, 389-97.

Gee, D. G., Kumpulainen, R., Roberts, D., Stephens, M. B., THON, A. \& ZACHRISSON, E. 1985b. Scandinavian Caledonides - Tectonostratigraphic map. In The Caledonide Orogen - Scandinavia and Related Areas (eds D. G. Gee \& B. A. Sturt). Chichester: Wiley.

Gee, D. G., Kumpulianen, R. \& Thelander, T. 1978. The Tåsjön Décollement, central Swedish Caledonides. Sveriges Geologiska Undersökning C742, 1-35.

GilotTI, J. \& KUMPULAINEN, R. 1986. Strain softening induced ductile flow in the Särv thrust sheet, Scandinavian Caledonides. Journal of Structural Geology 8, 441-55.

GrasemanN, B., Fritz, H. \& VANNAY, J.-C. 1999. Quantitative kinematic flow analysis from the Main Central Thrust Zone (NW Himalaya, India): implications for a decelerating strain path and the extrusion of orogenic wedges. Journal of Structural Geology 21, 837-53.

GREILING, R. O. 1985. Strukturelle und metamorphe Entwicklung an der Basis grosser, weittransportierter Deckeneinheiten am Biespiel des Mittleres Allochthons in den zentralen Skandinavischen Kaledoniden (StalonDeckenkomplex in Västerbotten, Schweden). Geotektonik Forschung 69, 1-129.

GREILING, R. O. 1988. RANSEREN Berggunnkarte 2025 3, 1:50,000, Foreløpig utgave. Trondheim: Norges Geologiske Undersøkelse.

GREILING, R. O. 1989. The Middle Allochthon in Västerbotten, northern Sweden: tectonostratigraphy and tectonic evolution. In The Caledonide Geology of Scandinavia (ed. R. A. Gayer), pp. 69-78. London: Graham \& Trotman.

Greiling, R. O., GaYer, R. A. \& Stephens, M. B. 1993. A basement culmination in the Scandinavian Caledonides 
formed by antiformal stacking (Bångonåive, northern Sweden). Geological Magazine 130, 471-82.

Greiling, R. O., Grimmer, J. C., DE WAll, H. \& BJöRK, L. 2007. Mesoproterozoic dyke swarms in foreland and nappes of the central Scandinavian Caledonides: structure, magnetic fabrics and geochemistry. Geological Magazine 144, 525-46.

GRIMMER, J. C., GLODNY, J., DRUPPEL, K. \& GREILING, R. O. 2015. Early- to mid-Silurian extrusion wedge tectonics in the central Scandinavian Caledonides. Geology 43, $347-50$.

Hacker, B. R., Andersen, T. B., Root, D. B., Mehl, L., MatTinson, J. M. \& Wooden, J. L. 2003. Exhumation of high-pressure rocks beneath the Solund Basin, Western Gneiss Region of Norway. Journal of Metamorphic Geology 21, 613-29.

Hossack, J. R. 1976. Geology and structure of the Beito Window. Norges Geologiske Undersøkelse 327, 1-33.

HoSSACK, J. R. 1978. The correction of stratigraphic section for tectonic finite strain in the Bygdin area, Norway. Journal of the Geological Society, London 135, 229-41.

Hossack, J. R. \& COOPER, M. A. 1986. Collision tectonics in the Scandinavian Caledonides. In Collision Tectonics (eds M. P. Coward \& A. Ries), pp. 287-304. Geological Society of London, Special Publication no 19.

Hossack, J. R., Garton, M. R. \& Nickelsen, R. P. 1985. The geological section from the foreland up to the Jotun thrust sheet in the Valdres area, south Norway. In The Caledonide Orogen - Scandinavia and Related Areas (eds D. G. Gee \& B. A. Sturt), pp. 443-56. Chichester: Wiley.

Hurich, C. A., Palm, H., Dyrelius, D. \& Kristoffersen, Y. 1989. Deformation of the Baltic continental crust during Caledonian intracontinental subduction: Views from seismic reflection data. Geology 17, 423-5.

JOHANSSON, L. \& MÖLLER, C. 1986. Formation of sapphirine during retrogression of basic high pressure granulite, Roan, Western Gneiss Region, Norway. Contributions to Mineralogy \& Petrology 94, 29-41.

Johnson, H. D., Levell, B. K. \& SiedLeCKI, S. 1978. Late Precambrian sedimentary rocks in East Finnmark, North Norway and their relationship to the TrollfjordKomagelva Fault. Journal of the Geological Society, London 135, 517-33.

Juhlin, C., Hedin, P., GEe, D. G., LORENZ, H., KALSCHEUER, T. \& YAN, P. 2016. Seismic imaging in the eastern Scandinavian Caledonides: siting the $2.5 \mathrm{~km}$ deep COSC-2 borehole, central Sweden. Solid Earth Discussion, published online 15 January 2016, doi: 10.5.5194/se-2015-129.

Kinck, J. J., Husebye, E. S. \& LARsson, F. R. 1993. The Moho depth distribution in Fennoscandia and the regional tectonic evolution from Archean to Permian times. Precambrian Research 64, 23-51.

Kirkland, C. L., Daly, S. J. \& Whitehouse, M. J. 2006. Granitic magmatism of Grenvillian and late Neoproterozoic age in Finnmark: constraining pre-Scandian deformation in the Kalak Nappe Complex. Precambrian Research 145, 24-52.

KISCH, H. J. 1980. Incipient metamorphism of CambroSilurian clastic rocks from the Jåmtland Supergroup, Central Scandinavian Caledonides, Western Sweden: illite crystallininty and 'vitrinite' reflectance. Journal of the Geological Society, London 137, 271-88.

Kolstrup, M. L., PAsCal, C. \& MAupin, V. 2012. What compensates the topography of southern Norway? Insights from thermo-isostatic modeling. Journal of Geodynamics 61, 105-19.
KRILL, A. G. 1980. Tectonics of the Oppdal area, central Norway. Geologiska Föreningens $i$ Stockholm Förhandlingar 102, 523-30.

KRILL, A. G. 1985. Relationships between the Western Gneiss Region and the Trondheim region: Stockwerk tectonics reconsidered. In The Caledonide Orogen Scandinavia and Related Areas (eds D. G. Gee \& B. A. Sturt), pp. 475-84. Chichester: Wiley.

KRUHL, J. H. 1984. Deformation and metamorphism at the base of the Helgeland Nappe Complex, northwest of Grong (Northern Norway). Geologische Rundschau 73, 735-51.

KUMPULAINEN, R. 1980. Upper Proterozoic stratigraphy and depositional environment of the Tossåsfjället Group, Särv Nappe, southern Swedish Caledonides. Geologiska Föreningens $i$ Stockholm Förhandlingar 96, 531-50.

KUMPULAINEN, R. 2011. The Neoproterozoic glacigenic Lillfjället Formation, southern Swedish Caledonides. In The Geological Record of Neoproterozoic Glaciations (eds E. Arnaud, G. P. Halverson \& G. P. Shields-Zhou), pp. 629-34. Geological Society of London, Memoir no. 36.

KUMPULAINEN, R. \& GREILING, R. O. 2011. Evidence for late Neoproterozoic glaciation in the central Scandinavian Caledonides. In The Geological Record of Neoproterozoic Glaciations (eds E. Arnaud, G. P. Halverson \& G. P. Shields-Zhou), pp. 623-8. Geological Society of London, Memoir no. 36.

Kumpulainen, R. \& Nystuen, J. P. 1985. Late Proterozoic basin evolution and sedimentation in the westermost part of Baltoscandia. In The Caledonide Orogen - Scandinavia and Related Areas (eds D. G. Gee \& B. A. Sturt), pp. 213-32. Chichester: Wiley.

LINDQVIST, J.-E. 1984. A diamictite in the Nasafjäll Window, central Scandinavian Caledonides. Geologiska Föreningens $i$ Stockholm Förhandlingar 105, 223-7.

LINDQVIST, J.-E. 1988. Tectonic implications of U-, Mo-, and V-enriched graphitic phyllites in the Høgtuva and Nasafjäll Windows, Scandinavian Caledonides. Norsk Geologisk Tidsskrift 68, 187-99.

LINDQVIST, J.-E. 1990. Thrust related metamorphism in basement windows of the central Scandinavian Caledonides. Journal of the Geological Society, London 147, 69-80.

LINDQVIST, J.-E. \& JOHANSSON, L. 1987. Metamorphism and timing of thrusting in the Tømmerås Window. Central Scandinavian Caledonides. Geologiska Föreningens I Stockholm Förhandlingar 109, 135-46.

LiPPARD, S. J. \& RoBERTS, D. 1987. Fault systems in Caledonian Finnmark and the southern Barents Sea. Norges Geologiske Undersøkelse Bulletin 410, 55-64.

McClay, K. R. \& Price, N. J. (eds) 1981. Thrust and Nappe Tectonics. Geological Society of London, Special Publication no. 9. Oxford: Blackwell Scientific Publications. 539 pp.

MEAKIN, R. J. 1983. Geochemistry and tectonic implications of the basement and cover metadolerites from the West Coast Gneiss Region (Vestranden) of the central Scandinavian Caledonides. Geologiska Föreningens $i$ Stockholm Förhandlingar 104, 327-44.

MiLnes, A. G. \& KoESTLER, A. G. 1985. Geological structure of Jotunheimen, southern Norway (Sognefjell-Valdres cross-section). In The Caledonide Orogen - Scandinavia and Related Areas (eds D. G. Gee \& B. A. Sturt), pp. 457-74. Chichester: Wiley.

Milnes, A. G., WennBerg, O. P., SKar, Ø. \& Koestler, A. G. 1997. Contraction, extension and timing in the Southern Norwegian Caledonides the Sognefjord Transect. In Orogeny Through Time (eds J.-P. Burg \& M. Ford), 
pp. 123-48. Geological Society of London, Special Publication no. 121.

Milton, N. J. \& Williams, G. D. 1981. The strain profile above a major thrust fault, Finnmark, N. Norway. In Thrust and Nappe Tectonics (eds K. R. McClay \& N. J. Price), pp. 235-9. Geological Society of London, Special Publication no. 9.

MöLlER, C. 1988. Geology and metamorphic evolution of the Roan area, Vestranden, Western Gneiss Region, Central Norwegian Caledonides. Norges Geologiske Undersøkelse Bulletin 413, 1-31.

Morley, C. K. 1986. The Caledonian thrust front and palinspastic restorations in the southern Norwegian Caledonides. Journal of Structural Geology 8, 753-66.

MORLEY, C. K. 1987a. The structural geology of north Hadeland. Norsk Geologisk Tidsskrift 67, 39-49.

MoRLEY, C. K. 1987b. Lateral and vertical changes of deformation style in the Osen-Røa thrust sheet, Oslo Region. Journal of Structural Geology 9, 331-43.

MykKeltveit, S., Husebye, E. S. \& Oftedahl, C. 1980. Subduction of the Iapetus Ocean beneath the More Gneiss Region. Nature 288, 473-75.

NiCKElSEN, R. P. 1974. Geology of the RøssjøkollanDokkovatn area, Oppland. Norges Geologiske Undersøkelse 314, 53-100.

Nickelsen, R. P., HosSACK, J. R. \& GARTON, M. 1985. Late Precambrian to Ordovician stratigraphy and correlation in the Valdres-Synnfjell thrust sheets of the Valdres area, southern Norwegian Caledonides; with some comments on sedimentation. In The Caledonide Orogen - Scandinavia and Related Areas (eds D. G. Gee \& B. A. Sturt), pp. 369-78. Chichester: Wiley.

NielsEN, A. T. \& SCHOvsBO, N. H. 2006. Cambrian to basal Ordovician lithostratigraphy in southern Scandinavia. Bulletin of the Geological Society of Denmark 53, 4792.

Norton, M. G. 1986. Late Caledonian extension in Western Norway: a response to extreme crustal thickening. Tectonics 5, 195-204.

NySTUEN, J. P. 1981. The late Precambrian 'Sparagmites' of southern Norway: a major Caledonian Allochthon - the Osen-Røa Nappe Complex. American Journal of Science 281, 69-94.

NySTUEN, J. P. 1982. Late Proterozoic basin evolution on the Baltoscandian craton: the Hedmark Group, southern Norway. Norges Geologiske Undersøkelse 375, 1-74.

NySTUEN, J. P. 1983. Nappe and thrust structures in the Sparagmite Region, southern Norway. Norges Geologiske Undersøkelse 380, 67-83.

NYSTUEN, J. P. 1987. Synthesis of the tectonic and sedimentological evolution of the late Proterozoic-early Cambrian Hedmark Basin, the Caledonian Thrust Belt, southern Norway. Norsk Geologisk Tidsskrift 67, 395-418.

Nystuen, J. P., ANDRESEN, A., Kumpulainen, R. \& SIEDLECKA, A. 2008. Neoproterozoic basin evolution in Fennoscandia, East Greenland and Svalbard. Episodes 31, 35-43.

NyStUEN, J. P. \& ILEBEKK, S. 1981. Stratigraphy and Caledonian structures in the area between the Atnsjøen and Spekedalen windows, Sparagmite Region, southern Norway. Norges Geologiske Undersøkelse 6, 17-24.

NystUEN, J. P. \& SiedLECKA, A. 1988. The 'Sparagmites' of Norway. In Late Proterozoic Stratigraphy of the Northern Atlantic Region (ed. J. A. Winchester), pp. 237-52. Glasgow: Blackie.

Osmundsen, P. T., BraAthen, A., Nordgulen, O., Roberts, D., MEyer, G. B. \& EIDE, E. 2003. The Devonian Nesna shear zone and adjacent gneiss cored culmin- ations, North-Central Norwegian Caledonides. Journal of the Geological Society 160, 137-50.

Osmundsen, P. T., BraATHEN, A., SOMmaruga, A., Skilbrei, J. R., Nordgulen, O., Roberts, D., ANDERSEN, T. B., Olesen, O. \& MosAR, J. 2005. Metamorphic core complexes and gneiss-cored culminations along the mid-Norwegian margin: an overview and some current ideas. In Onshore-offshore Relationships on the Mid Norwegian Margin (eds B. Wandaas \& F. Gradstein), pp. 29-41. Norwegian Petroleum Society, Special Publication no. 12.

OTTERMÜLLER, L. \& MIDZI, V. 2013. The crustal structure of Norway from inversion of teleseismic receiver functions. Journal of Seismology 7, 35-48.

PAGE, L. M. 1993. Tectonostratigraphy and Caledonian structure of the Singis-Tjuoltajaure area, central Norbotten Caledonides, Sweden. Geologiska Föreningens $i$ Stockholm Förhandlingar 115, 165-80.

Palm, H., Gee, D. G., Dyrelius, D. \& BJørklund, L. J. O. 1991. A reflection seismic image of Caledonian structure in Central Sweden. Sveriges Geologiska Undersökning Ca75, 1-36.

PHARAOH, T. C. 1985. The stratigraphy and structure of autochthonous metasediments in the RepparfjordKomagfjord Tectonic Window, west Finnmark. In The Caledonide Orogen - Scandinavia and Related Areas (eds D. G. Gee \& B. A. Sturt), pp. 347-58. Chichester: Wiley.

PLINK-BJÖRKLUND, P., BJÖRKLUND, L. \& LOORENTS, K.-H. 2005. Sedimentary documentation of the break-up of Rodinia, Offerdal Nappe, Swedish Caledonides. Precambrian Research 136, 1-26.

RICE, A. H. N. 1987. Continuous out-of-sequence ductile thrusting in the Norwegian Caledonides. Geological Magazine 124, 249-60.

RICE, A. H. N. 1998. Stretching lineations and structural evolution of the Kalak Nappe Complex (middle Allochthon) in the Repparfjord-Fægfjord area, Finnmark, N. Norway. Norsk Geologisk Tidsskrift 78, 277-89.

RicE, A. H. N. 1999. The orogenic wedge in the central Scandinavian Caledonides: Scandian structural evolution and possible influence of the foreland basin - a discussion and alternative model. GFF 121, 73-4.

RicE, A. H. N. 2001. Field evidence for thrusting of the basement rocks coring tectonic windows in the Scandinavian Caledonides; an insight from the Kunes Nappe, Finnmark, Norway. Norsk Geologisk Tidsskrift 81, 3218

RICE, A. H. N. 2005. Quantifying the exhumation of the UHProcks in the Western Gneiss Region, S. W. Norway: a branch-line - balanced cross-section model. Austrian Journal of Earth Sciences 98, 2-21.

RICE, A. H. N. 2014. Restoration of the External Caledonides, Finnmark, North Norway. In New Perspectives on the Caledonides of Scandinavia and Related Areas (eds F. Corfu, D. Gasser \& D. M. Chew), pp. 271-99. Geological Society of London, Special Publication no. 390.

Rice, A. H. N., Bevins, R. E., Robinson, D. \& Roberts, D. 1989a. Thrust-related metamorphic inversion in the Caledonides of Finnmark, north Norway. In Evolution of Metamorphic Belts (eds J. S. Daly, R. A. Cliff \& B. W. D. Yardley), pp. 413-21. Geological Society of London, Special Publication no. 43.

Rice, A. H. N., GAYER, R. A., RoBinson, D. \& BEvins, R. E. 1989b. Strike-slip restoration of the Barents Sea Caledonides Terrane, Finnmark, North Norway. Tectonics $\mathbf{8}$, 247-64. 
Rice, A. H. N. \& TownSEND, C. 1996. Correlation of the late Precambrian Ekkerøya Formation (Vadsø Group; E. Finnmark) and the Brennelvfjord Interbedded Member (Porsangerfjord Group; W. Finnmark), N. Norwegian Caledonides. Norsk Geologisk Tidsskrift 76, 5561.

RicKARD, D. T., Willdén, M. Y., MARINDER, N.-E. \& DONNELLY, T. H. 1979. Studies on the genesis of the Laisvall sandstone lead-zinc deposit, Sweden. Economic Geology 74, 1255-85.

ROBERTS, D. 1989. Tectonostratigraphy within the area of 1:250,000 map-sheet 'Grong', Nord-Trøndelag, Central Norway. Geologiska Föreningens i Stockholm Förhandlingar 111, 404-7.

ROBERTS, D. 1997. Geologisk kart over Norge. Berggrunnsgeologisk kart GRONG, M 1:250000. Trondheim: Norges Geologiske Undersøkelse.

ROBERTS, D. \& LIPPARD, S. J. 2005. Inferred Mesozoic faulting in Finnmark: current status and offshore links. Norges Geologiske Undersøkelse Bulletin 443, 55-60.

Roberts, D. \& Stephens, M. B. 2000. 4. Caledonian Orogenic Belt. In Description of the Bedrock Map of Central Fennoscandia (Mid-Norden) (eds T. Lundqvist \& S. Autio), pp. 79-104. Geological Survey of Finland, Special Paper no. 28.

ROBERTS, J. D. 1974. Stratigraphy and correlation of Gaissa Sandstone Formation and Børslev Subgroup (Porsangerfjord Group), South Porsangerfjord, Finnmark. Norges Geologiske Undersøkelse 303, 57-118.

Robinson, P., RoberTs, D., GeE, D. G. \& Solli, A. 2014. A major synmetamorphic Early Devonian thrust and extensional fault system in the Mid-Norway Caledonides: relevance to exhumation of HP and UHP rocks. In New Perspectives on the Caledonides of Scandinavia and Related Areas (eds F. Corfu, D. Gasser \& D. M. Chew), pp. 241-70. Geological Society of London, Special Publication no. 390.

RODGERS, J. 1995. Lines of basement uplifts within the external parts of orogenic belts. American Journal of Science 295, 455-87.

RøE, S.-L. 2003. Neoproterozoic peripheral-basin deposits in eastern Finnmark, N. Norway: stratigraphic revision and palaeotectonic implications. Norwegian Journal of Geology 83, 259-74.

SCHOUENBORG, B. E. 1989. Primary and tectonic basementcover relationships in northernmost Vestranden, central Norwegian Caledonides. Norsk Geologisk Tidsskrift 69 , 209-23.

SiedLECKA, A. \& ILEBEKK, S. 1982. Forekomster av tillit på nordsiden av Atnsjøen-vinduet. Norges Geologiske Undersøkelse 373, 33-7.

SIMPSON, C. \& DE PAOR, D. G. 1997. Practical analysis of general shear zones using the porphyroclast hyperbolic distribution method: An example from the Scandinavian Caledonides. In Evolution of Geological Structures in Micro- to Macro-scales (ed S. Sengupta), pp. 169-84. London: Chapman Hall.

SjÖSTRÖM, H. \& TALBOT, C. 1987. Caledonian and postCaledonian structures of the Olden Window, Scandinavian Caledonides. Geologiska Föreningens $i$ Stockholm Förhandlingar 109, 359-61.

SNÄLL, S. 1988. Mineralogy and maturity of the alum shales of south central Jämtland, Sweden. Sveriges Geologiska Undersökning C818, 1-46.

SOLYOM, Z., GORBATSCHEV, R. \& JohanSSON, I. 1979. The Ottfjället dolerites. Geochemistry of the dyke swarm in relation to the geodynamics of the Caledonide oro- gen of Central Scandinavia. Sveriges Geologiska Undersökning C756, 3-38.

SOPER, N. J., STRACHAN, R. A., HOLDSWORTH, R. E., GAYER, R. A. \& GREILING, R. O. 1992. Sinistral transpression and the Silurian closure of Iapetus. Journal of the Geological Society, London 149, 871-80.

STEL, H. 1988. Basement-cover relations at the GrongOlden culmination, Central Norway. Norsk Geologisk Tidsskrift 68, 135-47.

SVERIGES GEOLOGISKA UNDERSÖKNING. 1984. Karta över Berggrunden I Jämtlands län. Uppsala: Sveriges Geologiska Undersökning, no. Ca53.

THELANDER, T. 1982. The Torneträsk Formation of the Dividal Group, northern Swedish Caledonides. Sveriges Geologiska Undersökning Ba16, 69-110.

THELANDER, T., BAKKER, E. \& NICHOLSON, R 1980. Basement-cover relationships in the Nasafjället Window, central Swedish Caledonides. Geologiska Föreningens $i$ Stockholm Förhandlingar 102, 569-80.

TORGERSEN, E. \& ViOLA, G. 2014. Structural and temporal evolution of a reactivated brittle-ductile fault - Part I: Fault architecture, strain localization mechanisms and deformation history. Earth \& Planetary Science Letters 407, 205-20.

TOWNSEND, C. 1987. Thrust transport directions and thrust sheet restoration in the Caledonides of Finnmark. Journal of Structural Geology 9, 345-52.

Townsend, C., Rice, A. H. N. \& MACKAY, A. 1989. The structure and stratigraphy of the southwestern portion of the Gaissa Thrust Belt and the adjacent Kalak Nappe Complex. In The Caledonide Geology of Scandinavia (ed R. A. Gayer), pp. 111-26. London: Graham \& Trotman.

Townsend, C., Roberts, D., Rice, A. H. N. \& GAYeR, R. A. 1986. The Gaissa Nappe, Finnmark, North Norway: an example of a deeply eroded external imbricate zone within the Scandinavian Caledonides. Journal of Structural Geology 8, 431-40.

TUCKER, M. 1976. Replaced evaporites from the late Precambrian of Finnmark, Arctic Norway. Sedimentary Geo$\log y$ 16, 193-204.

TUCKER, M. 1977. Stromatolitic biostromes and associated facies in the late Precambrian Porsanger Dolomite Formation of Finnmark, Arctic Norway. Palaeogeography, Palaeoclimatology, Palaeoecology 21, 5583.

WARR, L. N., GreILING, R. O. \& ZACHRISSON, E. 1996 Thrust-related very low grade metamorphism in the marginal part of an orogenic wedge, Scandinavian Caledonides. Tectonics 15, 1213-29.

White, B. 1968. The Porsanger Sandstone Formation and subjacent rocks in the Lakselv Valley District, Finnmark, Northern Norway. Norges Geologiske Undersøkelse 255, 59-86.

WhITE, B. 1969. The Stabbursnes Formation and Porsanger Dolomite Formation in the Kolvik district, northern Norway: the development of a Pre-Cambrian algal environment. Norge Geologiske Undersøkelse 258, 79115 .

WILLIAMS, D. M. 1976a. A revised stratigraphy of the Gaissa Nappe. Norges Geologiske Undersøkelse 324, 79115.

WiLliams, D. M. 1976b. Clastic dykes from the Precambrian Porsangerfjord Group, North Norway. Geological Magazine 113, 169-76.

Williams, G. D., Milton, N. J. \& Chapman, T. J. 1984 Generation and modification of finite strain patterns by 
progressive thrust faulting in the Laksefjord Nappe, Finnmark. Tectonophysics 107, 177-86.

Worsley, D., BaArli, B. G., Howe, M. P. A., Hualtasan, F. \& ALM, D. 2011. New data on the Bruflat Formation and the Llandovery/Wenlock transition in the Oslo Region. Norwegian Journal of Geology 91, 101-20.
ZACHRISSON, E. 1964. The Remdalen Syncline. Sveriges Geologiska Undersökning C596, 153.

ZACHRISSON, E. 1969. Caledonian geology of northern Jämtland-southern Västerbotten. Sveriges Geologiska Undersökning C644, 1-33. 